\title{
Population Genetic Structure of Venturia effusa, Cause of Pecan Scab, in the Southeastern United States
}

\author{
Clive H. Bock, Michael W. Hotchkiss, Carolyn A. Young, Nikki D. Charlton, Mattupalli Chakradhar, \\ Katherine L. Stevenson, and Bruce W. Wood
}

First, second, and seventh authors: United States Department of Agriculture-Agricultural Research Service Southeastern Fruit and Tree Nut Research Laboratory, Byron, GA 31008; third, fourth, and fifth authors: The Samuel Roberts Noble Foundation, 2510 Sam Noble Parkway, Ardmore, OK 73401; sixth author: Department of Plant Pathology, Coastal Plain Experiment Station, University of Georgia, Tifton 31793. Accepted for publication 12 January 2017.

\begin{abstract}
Venturia effusa is the most important pathogen of pecan in the southeastern United States. Little information exists on the population biology and genetic diversity of the pathogen. A hierarchical sampling of 784 isolates from 63 trees in 11 pecan orchards in the southeastern United States were screened against a set of 30 previously characterized microsatellite markers. Populations were collected from Georgia $(n=2)$, Florida $(n=1)$, Alabama $(n=2)$, Mississippi $(n=1)$, Louisiana $(n=1)$, Illinois $(n=1)$, Oklahoma $(n=1)$, Texas $(n=1)$, and Kansas $(n=1)$. Clonality was low in all orchard populations $(\leq 10.1 \%$ of isolates), and there were consistently high levels of genotypic diversity (ShannonWeiner's index $=3.49$ to 4.59 ) and gene diversity (Nei's measure $=0.513$ to 0.713 ). Analysis of molecular variance showed that, although $81 \%$ of genetic diversity occurred at the scale of the individual tree, $16 \%$ occurred between orchards and only $3 \%$ between trees within orchards. All populations could be differentiated from each other $(P=0.01)$, and various cluster analyses indicated that some populations were more closely related compared with other pairs of populations. This is indicative of some limited population differentiation in $V$. effusa in the southeastern United States. Bayesian and nearest-neighbor methods

suggested eight clusters, with orchards from Georgia and Florida being grouped together. A minimum spanning tree of all 784 isolates also indicated some isolate identification with source population. Linkage disequilibrium was detected in all but one population (Kansas), although 8 of the 11 populations had $<20 \%$ of loci at disequilibrium. A Mantel test demonstrated a relationship between physical and genetic distance between populations $(Z=11.9, r=0.559, P=0.001)$. None of the populations were at mutation-drift equilibrium. All but 3 of the 11 populations had a deficiency of gene diversity compared with that expected at mutation-drift equilibrium (indicating population expansion); the remaining populations had an excess of gene diversity compared with that expected at mutation-drift equilibrium (indicating a recent bottleneck). These observations are consistent with the known history of pecan and pecan scab, which is that $V$. effusa became an issue on cultivated pecan in the last approximately 120 years (recent population expansion). Recently reported mating type genes and the sexual stage of this fungus may help explain the observed population characteristics, which bear a strong resemblance to those of other well-characterized sexually reproducing ascomycete pathogens.
\end{abstract}

Pecan production has been widespread in the southeastern United States for over 100 years, and it has become an increasingly important specialty crop: in 2015 , production in the United States was $1.15 \times 10^{8} \mathrm{~kg}$, valued at $\$ 5.60 \times 10^{8}$ (NASS 2015). Several factors, including various diseases, affect yield of pecan (Teviotdale et al. 2002). The most important disease of pecan is scab, caused by the plant-pathogenic fungus Venturia effusa (G. Winter) Rossman \& W. C. Allen (previously Fusicladium effusum G. Winter) (Rossman et al. 2016), which is widespread in the humid southeastern United States (Bock et al. in press; Demaree and Cole 1929). Conidia of the pathogen are spread in rain splash and wind (Gottwald and Bertrand 1982) and can infect young, expanding foliage (Gottwald 1985) and developing or mature fruit (Stevenson and Bertrand 2001). When scab epidemics develop, the consequences of reduced yield can be severe (Gottwald and Bertrand 1983; Stevenson and Bertrand 2001). The pecan industry continues to expand, and growers choose cultivars that are commonly available from nurseries and that have preferred agronomic characteristics, particularly in relation to

Corresponding author: C. H. Bock; E-mail address: clive.bock@ars.usda.gov

*The $e$-Xtra logo stands for "electronic extra" and indicates that three supplementary figures are published online.

This article is in the public domain and not copyrightable. It may be freely reprinted with customary crediting of the source. The American Phytopathological Society, 2017. marketability of nuts (size, color, and flavor), date of harvest, and stability of bearing, despite these cultivars often being scabsusceptible (Wells 2014). Scab resistance in the southeastern United States is an important characteristic but is by no means the major consideration in choosing a cultivar. Once planted, the trees are long lived, and can remain in an orchard for many decades (in some cases a hundred years or more).

Pecan scab is a problematic disease to control. The pathogen has developed resistance to fungicides used to manage it (Stevenson 1999; Stevenson et al. 2014) and it has demonstrated pathogenic variability, with specific isolates generally infecting only a small range of cultivars (Conner and Stevenson 2004). The ability of the pathogen to adapt to and overcome resistance has resulted in several previously resistant host cultivars becoming susceptible over time (Goff et al. 1996). The basis for the adaptability resides in the characteristics of the genetic diversity, which has been partially determined based on dominant molecular markers (Bock et al. 2014a,b), and on the reproductive strategy of $V$. effusa, which has received limited attention. Dominant marker systems can be useful but they are often considered less reliable or informative (Ellsworth et al. 1993; Novelo et al. 2010) compared with codominant marker systems. Nonetheless, the study of Bock et al. (2014b) found substantial genetic diversity, which was hierarchically distributed, with most diversity evident at the scale of a few to tens of meters (the scale of a tree). Very recently, significant advances have been made in understanding the reproduction of $V$. effusa. Initially, researchers established that asexually produced conidia were responsible for 
infections (Demaree 1924; Gottwald and Bertrand 1982) but there was no evidence of a sexual stage. Preliminary reports on the identification of mating type idiomorphs in V. effusa (C. A. Young and N. D. Charlton, personal communications) have now been followed by observations confirming development of the sexual stage (typical Venturia-like pseudothecia and ascospores) in vitro (C. A. Young and N. D. Charlton, personal communications). However, the importance of the sexual stage in both the genetics and epidemiology of the pathogen remain to be established.

A fundamental and thorough understanding of the genetic diversity and population structure of ascomycete fungal pathogens is basic to effective management of the host crop diseases they cause (McDonald and Linde 2002; McDonald and Mundt 2016; Stukenbrock and McDonald 2008). Furthermore, it can provide valuable information on the origins and spread of a pathogen, and timing of events affecting spread, including bottlenecks or founder effects in populations of a pathogen (Gladieux et al. 2010; Linde et al. 2009; McDonald and Mundt 2016). Pathogens of several important crops have now been characterized in regard to their regional or global genetic diversity and population structure, including Zymoseptoria tritici (syn. Septoria tritici or Mycosphaerella graminicola) (Quaedvlieg et al. 2011) on wheat (Linde et al. 2002; McDonald et al. 1995), Rhynchosporium commune (syn. $R$. secalis) (Zaffarano et al. 2011) on barley (Linde et al. 2009; McDonald 2015) V. inaequalis on apple (Gladieux et al. 2008, 2010; Tenzer and Gessler 1999) and Alternaria brassicicola on sea rocket Cakile martima) (Bock et al. 2005; Linde et al. 2010). All these pathogen populations are characterized by moderate to high genetic diversity and low clonality (where it occurs, clonality is mostly at small spatial scales due to asexual reproduction). Although asexual stages have not been characterized for all these species (in particular, $R$. commune and A. brassicicola), the mating type idiomorphs have been identified and found to be in equilibrium, which is strongly indicative of regular meiosis. $V$. effusa is phylogenetically related to the above species of ascomycetes but is genetically most closely related to $V$. inaequalis (Bock et al. 2016b; Schubert et al. 2003; Seyran et al. 2010); in addition, there are similarities between their hosts and modes of production. Apple and other close relatives are temperate, deciduous trees, much like pecan and closely related species of Carya, which are grown in orchards that are long lived and often spatially scattered over large geographic distances (although, in some areas, such as the counties surrounding Albany, GA, pecan orchards are often contiguous and more densely planted). Isolated patches of one or several trees in woodlands, hedgerows, or residential yards may occur sporadically between orchards or native populations of pecan. Individual pecan trees vary greatly in susceptibility to scab, depending on cultivar or native genotype (Conner and Stevenson 2004), which can add a further filter to migration of the pathogen among orchards and trees. Furthermore, trees, unlike annual cereal crops, have very long generation times compared with their associated pathogens, which might promote various compensations (Petit and Hampe 2006). V. inaequalis reproduces both sexually and asexually, with the sexually produced ascospores generally initiating epidemics early in the season, with much subsequent spread by recurring cycles of asexually produced conidia. However, although $V$. effusa reproduces asexually, the role of the recently identified sexual stage remains uncharacterized, and the population biology poorly defined. Indeed, as Gladieux et al. (2010) pointed out, "little attention has been paid to the impact of host domestication on the population genetics of fungi that infect trees domesticated for fruit or wood production". With pecan, neither the characteristics of the population genetics of $V$. effusa on native trees nor how those characteristics relate to those of populations on domesticated trees are known.

Research of the population genetic diversity, structure, and dynamics of the apple scab fungus in Eurasia has shown how the pathogen has coevolved with its host and the resulting impact of domestication of apple on that genetic differentiation (Gladieux et al. 2008, 2010; Guérin et al. 2007; Tenzer and Gessler 1999). Some annual crop pathogens (e.g., Z. tritici, R. commune, and Leptosphaeria maculans) have been very well characterized (McDonald and Linde 2002; Linde et al. 2009; McDonald et al. 2015; Stukenbrock et al. 2011; Zaffarano et al. 2006; Zhan et al. 2003), which has led to an even more advanced knowledge base that has resulted in valuable insights into the host-pathogen relationship and has also been a basis for developing informed, improved disease management approaches for these pathosystems. First, understanding the population biology of a pathogen provides the basis for targeting the search for the most diverse and durable resistance. Second, it provides knowledge on the level of gene flow which informs the need for regional management of the disease (managing on a field-by-field basis will be of limited value if the inoculum can travel and disperse and eventually recombine virulence genes). Third, the knowledge establishes the variability of quantitative traits at different spatial scales and informs the need for which, and how many management practices might be needed to impose trade-off selection on the pathogen and, eventually, identification of virulence factors that can provide the basis for selection of appropriate resistance genes in the host. In contrast, the current level of knowledge and understanding of the population structure and genetic diversity, not to mention virulence factors in $V$. effusa and resistance genes in pecan, is rudimentary at best.

A draft genome of $V$. effusa was recently published (Bock et al. 2016b). This was mined for codominant, microsatellite markers that were screened against an initial set of isolates to ensure polymorphicity of markers, and consistency and reliability of polymerase chain reaction (PCR) amplification among isolates (Bock et al. 2016a). More than 30 microsatellites were characterized. The objectives of this study were to use these microsatellite markers to characterize the population genetic diversity and structure of V. effusa in the southeastern United States, and to determine the status in relation to recent events that might have affected those populations (bottlenecks or founder effects, and recent population expansions) across the endemic area of the pathogen in the southeastern United States.

\section{MATERIALS AND METHODS}

Sample locations and isolation of $\boldsymbol{V}$. effusa. In total, 784 isolates of $V$. effusa were sampled from scab-diseased leaves or fruit of pecan from 11 populations across the southeastern region of the United States (Table 1; Fig. 1) (Bock et al. 2014b). Up to 19 individual diseased leaflets or fruit were collected from three to six trees in each of the orchards, ensuring that the leaflet samples were taken from around the canopy of each tree. The $\leq 6$ sampled trees in each orchard were selected on a grid pattern, such that individual pairs of trees in the grid were separated from each other by at least 4 trees. In some cases, due to orchard size or shape, slight modifications were needed for the grid. The resulting sampling was hierarchical, consisting of a regional scale (between orchards, approximately 100 to $1,300 \mathrm{~km}$ ), between trees within an orchard (approximately 50 to $140 \mathrm{~m}$ ), and between leaflets on an individual tree (approximately 2 to $20 \mathrm{~m}$ ). Isolates were sampled from orchards of commercially available grafted cultivars and naturally seeded native-tree groves.

The procedures for isolation of V. effusa from scabbed leaflets or from fruit have been described previously (Bock et al. 2014a). Briefly, conidia of $V$. effusa were scraped from single lesions on the sample using a scalpel, and a dilute spore suspension was prepared in sterile distilled water. Multiple 100- $\mu$ l aliquots were spread on the surface of replicate water agar plates (WA, amended with lactic acid [0.50 ml/liter], streptomycin [0.20 g/liter], tetracycline [0.05 g/liter], and chloramphenicol [0.05 g/liter]). Spreads were incubated at $25^{\circ} \mathrm{C}$ for $24 \mathrm{~h}$ under fluorescent lights on a 12-and-12-h photoperiod. Operating under a stereoscopic microscope at $\times 50$ to $\times 70$, a single 
germinated spore of $V$. effusa was subsequently excised on an agar plug using a scalpel and transferred to antibiotic-amended potato dextrose agar (amended as for WA). The culture was incubated as described for 3 to 5 weeks at $25^{\circ} \mathrm{C}$.

DNA extraction, PCR, and genotyping. Mycelium (approximately $200 \mathrm{mg}$ ) was scraped from the surface of the colony of $V$. effusa using a scalpel. DNA was extracted using a Zymo Research DNA extraction kit (Zymo Research, Irvine, CA), following a slightly modified protocol for DNA extraction from fungi (Seyran et al. 2010). A TissueLyser (Qiagen, Valencia, CA) was used to lyse the fungal mycelium. DNA was quantified using a NanoDrop spectrophotometer (NanoDrop Products, Wilmington, DE) and stored in Tris-EDTA buffer at $-20^{\circ} \mathrm{C}$.

The 30 microsatellite primers (Table 2, obtained from Eurofins MWG Operon, Huntsville, AL) were developed from a draft genome of $V$. effusa and have been previously described and found to be reliable and repeatable (Bock et al. 2016a). For the PCR assay, the working microsatellite primer concentration was $10 \mu \mathrm{M}$, and the reaction volume $(5 \mu \mathrm{l})$ contained $1.5 \mu \mathrm{l}$ of template DNA (1.5 to $2.0 \mathrm{ng}), 0.25 \mu \mathrm{l}$ of primer, $0.75 \mu \mathrm{l}$ of distilled $\mathrm{H}_{2} \mathrm{O}$, and $2.5 \mu \mathrm{l}$ of master mix (Promega Corp., Madison, WI). PCR conditions were an initial denaturation at $94^{\circ} \mathrm{C}$ for $1 \mathrm{~min}$; followed by $94^{\circ} \mathrm{C}$ for $40 \mathrm{~s}$, $58^{\circ} \mathrm{C}$ for $40 \mathrm{~s}$, and $72^{\circ} \mathrm{C}$ for $20 \mathrm{~s}$ (repeated 33 times); and a final primer extension step at $72^{\circ} \mathrm{C}$ for $30 \mathrm{~min}$. Primers were labeled with either FAM, NED, HEX, or PET dye (some were labeled with M13 tails). Use of M13 tails provides a method to label only a single primer (the forward primer), and reduces the cost of the reaction (Schuelke 2000). Once PCR conditions were confirmed using gel electrophoresis (Bock et al. 2016a), all marker-primer combinations were processed on a Hitachi 3500 Genetic Analyzer (ThermoFisher Scientific, Grand Island, NY). Resulting amplicon peaks were scored by base pair size for each marker using GeneMarker (SoftGenetics, State College, PA). Being a haploid organism, only a single band was observed at each locus for each isolate.

Data analysis. The population genetic diversity and structure was based on the haploid multilocus genotypes (MLG) and allele presence and frequency in the populations. Although some basic statistics were generated using the raw data, subsequent analyses described are based on clone-corrected data. Many analyses of genetic diversity are sensitive to the presence of more than one MLG per population; furthermore, clone-corrected populations approximate in behavior to sexual populations. For these reasons, clones were censored. Isolates were hierarchically grouped according to source orchard and source tree within orchard. Various orchard-level population genetic indices were calculated using the $\mathrm{R}$ package poppr (Kamvar et al. 2014), including the number of MLG observed, the clone-corrected number of MLG, the expected MLG (eMLG, which measures genotypic richness) at the smallest sample size based on rarefaction (and the standard error of eMLG), genotypic diversity (which measures both genotypic richness and abundance and was measured using the Shannon-Wiener index of MLG diversity [H]) (Shannon 2001), Stoddart and Taylor's index of MLG diversity (G) (Stoddart and Taylor 1988), and Simpson's index $(\lambda)$ (Simpson 1949). Evenness measures the distribution of genotype abundances and is measured on a scale of 0 to 1 , where a population with equally abundant genotypes has a value equal to 1 and a population with a high frequency of individual genotypes compared with others is closer to zero (calculated as E0.5)

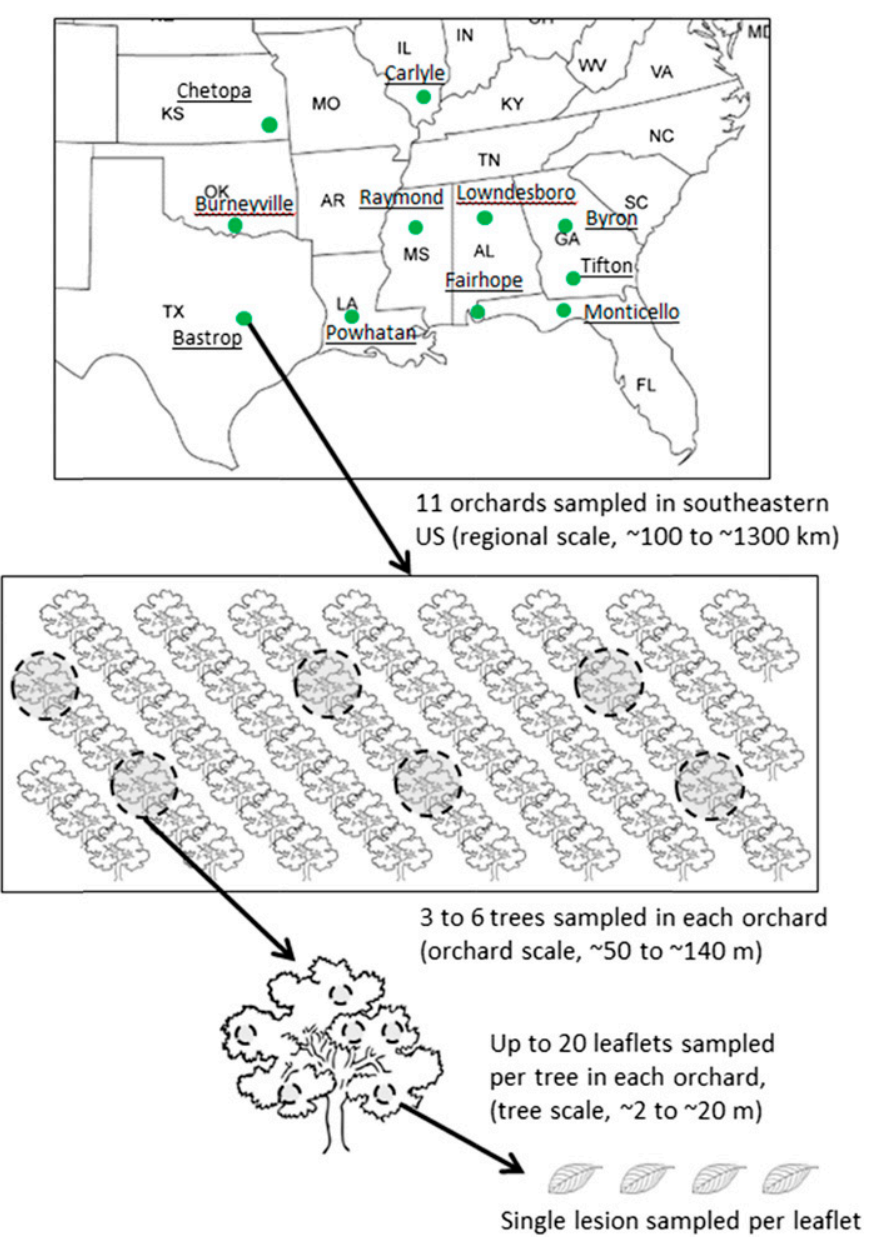

Fig. 1. Sites and protocols for sampling from populations of Venturia effusa collected for population genetic analysis from pecan orchards in the southeastern United States. A hierarchical sampling protocol was followed to obtain scab isolates from up to 19 individual leaves or fruit from up to six trees in each of 11 orchards of pecan. Sampling comprised the regional scale (between orchards, approximately 100 to $1,300 \mathrm{~km}$ ), between trees within an orchard (approximately 50 to $140 \mathrm{~m}$ ), and between leaves on an individual tree (approximately 2 to $20 \mathrm{~m}$ ).

TABLE 1. Location, elevation, cultivar, and number of isolates of Venturia effusa collected to assess population genetic diversity (Bock et al. 2014b) ${ }^{\mathrm{a}}$

\begin{tabular}{|c|c|c|c|c|c|c|}
\hline Source location (population) & Trees & Isolates & Latitude and longitude of site & Elev (m) & Pecan cultivar & Desig \\
\hline Fairhope, AL & 6 & 93 & $\mathrm{~N} 30^{\circ} 32.681^{\prime}, \mathrm{W} 87^{\circ} 52.918^{\prime}$ & 62 & Desirable & AL-F \\
\hline Lowndesboro, AL & 6 & 91 & $\mathrm{~N} 32^{\circ} 21.236^{\prime}, \mathrm{W} 86^{\circ} 38.393^{\prime}$ & 43 & Kiowa & AL-L \\
\hline Byron, GA & 6 & 63 & $\mathrm{~N} 32^{\circ} 65.522^{\prime}, \mathrm{W} 83^{\circ} 65.522^{\prime}$ & 156 & Desirable & GA-B \\
\hline Chetopa, KS & 3 & 34 & $\mathrm{~N} 37^{\circ} 01.360^{\prime}, \mathrm{W} 95^{\circ} 02.783^{\prime}$ & 266 & Native seedling & KS \\
\hline Powhatan, LA & 6 & 68 & $\mathrm{~N} 31^{\circ} 50.211^{\prime}, \mathrm{W} 93^{\circ} 13.328^{\prime}$ & 33 & Desirable & LA \\
\hline Raymond, MS & 6 & 89 & $\mathrm{~N} 32^{\circ} 11.297^{\prime}, \mathrm{W} 90^{\circ} 29.537^{\prime}$ & 70 & Desirable & MS \\
\hline Monticello, FL & 6 & 52 & $\mathrm{~N} 30^{\circ} 32.265^{\prime}, \mathrm{W} 83^{\circ} 55.060^{\prime}$ & 69 & Desirable & FL \\
\hline Burneyville, OK & 6 & 103 & $\mathrm{~N} 33^{\circ} 52.823^{\prime}, \mathrm{W} 97^{\circ} 15.164^{\prime}$ & 244 & Western Schley & $\mathrm{OK}$ \\
\hline Tifton, GA & 6 & 45 & N $31^{\circ} 30.388^{\prime}$, W 83v38.287' & 112 & Desirable & GA-T \\
\hline Bastrop, TX & 6 & 93 & $\mathrm{~N} 30^{\circ} 03.554^{\prime}, \mathrm{W} 97^{\circ} 18.402^{\prime}$ & 123 & Wichita & $\mathrm{TX}$ \\
\hline Carlyle, IL & 6 & 53 & N $38^{\circ} 29.323^{\prime}$, W $89^{\circ} 30.212^{\prime}$ & 143 & Native seedling & IL \\
\hline Total & $\ldots$ & 784 & $\cdots$ & $\ldots$ & $\ldots$ & $\ldots$ \\
\hline
\end{tabular}

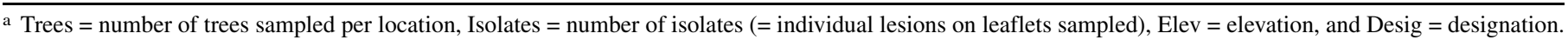


(Grünwald et al. 2003; Ludwig and Reynolds 1988; Pielou 1975). $E 0.5$ is considered a robust measure of evenness because it is not as dependent on the number of genotypes in a sample (Grünwald et al. 2003). Nei's unbiased gene diversity was also calculated $\left(\mathrm{H}_{\exp }\right)(\mathrm{Nei}$ 1978).

Linkage disequilibrium was explored using the index of association $\left(I_{A}\right)$ (Brown et al. 1980), which measures whether loci are linked. A second measure of linkage disequilibrium $\left(\bar{r}_{d}\right)$ was calculated; this metric has the advantage of being independent of the number of loci (Agapow and Burt 2001). Significance of $I_{A}$ and $\bar{r}_{d}$ was tested by its deviation from the expected value (zero), with 1,000 randomizations performed for each population. These metrics were calculated using poppr.

The following were performed in GenAlEx 6.05 (Peakall and Smouse 2012). Pairwise population genetic identity was calculated based on Nei's measure of genetic identity and genetic distance between populations was based on Nei's unbiased measure of genetic distance (Nei 1973, 1978, 1987). In addition, genetic distance and associated probabilities were calculated using $\phi_{\mathrm{PT}}$, with higher values of $\phi_{\mathrm{PT}}$ indicating more divergence between populations (based on 1,000 permutations). Gene flow between orchard populations was approximated using the estimated mean number of migrants of $V$. effusa across loci per generation, $\left(N_{m}\right)$ which is based on the $\phi_{\mathrm{PT}}$ values between each pair of populations. Genetic structure of the populations was further explored using analysis of molecular variance (AMOVA) (based on 1,000 permutations), which was conducted at three spatial scales: diversity at the level of orchards in the southeastern region, trees within individual pecan orchards, and within individual trees (isolates from single lesions on leaflets sampled from individual trees). A principal coordinate analysis (PCoA) was performed to visualize patterns of variation within and between populations at the orchard and tree level based on Nei's unbiased measure of genetic distance.
The genetic analysis software Structure V2.3.4 (Falush et al. 2007; Pritchard et al. 2000), which assigns individuals to preselected clusters using a Bayesian model, was used to further determine clustering $(K)$ of the isolates and their relatedness among populations. In total, 20 independent runs each of $K=1$ to 11 were performed. A burn-in of 10,000 iterations was followed by 50,000 Monte Carlo Markov chain repetitions using an admixture model. The number of clusters that best represented the observed data were determined as follows. Initially, the relationship between the probability $[\operatorname{Pr}(X / K)]$ of the data for a particular $K$ was calculated (along with the standard deviation of the 20 estimates), and was graphed against $K$ (1 to 11 ). Due to peaks in $\operatorname{Pr}(X / K)$ often failing to reliably detect the true $K$, Evanno et al. (2005) developed an ad hoc quantity $(\Delta K)$ based on the second-order rate of change of $\operatorname{Pr}(X / K)$ that shows a clear peak at true $K$. The estimated membership coefficient of each individual in each cluster $(Q)$ was calculated, and represented graphically by showing each isolate as a vertical line partitioned into $K$ colored segments that represent an individual's estimated membership fraction in each of the inferred clusters at $K=1$ to 11 .

A minimum spanning network analysis was performed using Arlequin V3.5 (Excoffier et al. 2005) and the resulting data were imported to Gephi V0.8.2 (Bastian et al. 2009) to visualize and represent patterns in data. We generated a minimum spanning tree (using the algorithms Force Atlas and Force Atlas 2) connecting the 784 different isolates based on the analysis from Arlequin with a modularity of eight clusters $(K=8$, which was estimated as the number of clusters best representing these data using the earlier Bayesian analysis from Structure V2.3.4).

Historical (during the last approximately 100 years) population expansions or founder effects (bottlenecks) were explored by studying deviations in gene diversity (heterozygosity $[\mathrm{H}]$ ) from that expected at mutation-drift equilibrium $\left(\mathrm{H}_{\mathrm{EQ}}\right)$ among the different populations using the program Bottleneck V1.2 (Piry et al. 1999).

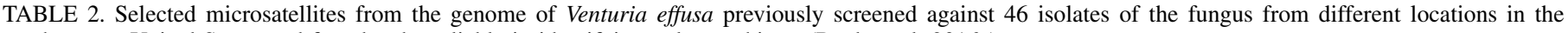
southeastern United States and found to be reliable in identifying polymorphisms (Bock et al. 2016a)

\begin{tabular}{|c|c|c|c|}
\hline Primer name ${ }^{a}$ & Forward primer sequence & Reverse primer sequence & Size (bp) \\
\hline Fe005_CAG8 & AGCAGAGAACCTATACACACG & AAGAAACAGCACACTGTCAAC & $170-200$ \\
\hline Fe015_GGA5 & ATCTGGATTGTCCCTTTTCT & CGCATACTTCTACGGCTACTA & $168-205$ \\
\hline Fe029_TCCCGG3 & CATTGGGTCCTACAGAGGTA & CAAATCTTCTCTAGCATACCG & $166-181$ \\
\hline Fe048_AC6 & CTCCCGATCTTCTCACTCTAT & GTTCCAAACTCAGAAGAAGTG & $149-193$ \\
\hline Fe050_CA6 & CAATGACGATGTCGGTAAC & ACCGTCTCATACCTACCAGTT & $193-288$ \\
\hline Fe052_CAA4 & ATTTACCAAGAGACCCAGGTA & AGCCTCAAGCTTAGCTCAC & $140-161$ \\
\hline Fe063_GAC4 & TTTGACTCGGCAGACACT & GTATTGCCTGTATTGCCTGTA & $152-206$ \\
\hline Fe069_GAA5 & GATGAGAGCAATGCTGATATG & CTTGTATGGATATGGATCTGG & $146-186$ \\
\hline Fe070_AAG4 & GATGAGAGCAATGCTGATATG & CTTGTATGGATATGGATCTGG & $120-164$ \\
\hline Fe072_TTG5 & TCGAAAGTCAAACGAAGGT & GGATTGATATACCTCGAGACC & $162-184$ \\
\hline Fe083_AGG4 & CGTGTGTTATACGATCATAGGT & CTACTCCAAAGGTTGTTCTCC & $176-184$ \\
\hline Fe089_CTCA3 & ATTGACTTTCCATCACTCGT & CCGTCAATGTCATCAAGTATC & $136-153$ \\
\hline Fe096_ACCTGT3 & TAAGTGACAACAACCTTCTGC & ACTAGGGAGGTAGCGAGAGTA & $99-130$ \\
\hline Fe097_AGGAGC3 & GCATGAGGACTGAAAGTAGTG & ССТTTTATATACGCTCСТCСТ & $230-239$ \\
\hline Fe139_CT8 & CCACCAATCGATATGAAGAT & GCAGGTAGCCTGATTAATTTC & $174-261$ \\
\hline Fe146_TCA8 & GGTATTCCTGTTTCGCAAG & TCCAACAGTGTGTATGATGTG & $113-248$ \\
\hline Fe170_AG7 & CAGTATCCAGTGGTTTTCGTA & TCATGAGTGCACTTCTTTTG & $126-159$ \\
\hline Fe179_CTT6 & TGGTAGGAGATGAAGAACTGA & GGGTATGTAAATCGTGAAACC & $154-207$ \\
\hline Fe189_CAG5 & TCGAGTCTTGGATGTAGGTAA & AGTATGATGGCGATGGACT & $170-223$ \\
\hline Fe190_CAC7 & ATGCTCACGTCTTCAAGTG & CACGACGACAAATGGTAAG & $164-192$ \\
\hline Fe196_GGAT3 & GTATCATTCCACACTCTTTCG & GTTTCGACAACTCATCAAGTG & $170-178$ \\
\hline Fe214_TGT6 & GATAAGGCACCTGAAGCTAAT & GAATTGGGTGTTGAAAGTGT & $162-189$ \\
\hline Fe216_CCA9 & CATCAACAACCACAACAACA & CATGGCATGGTAGTATACGTG & $203-239$ \\
\hline Fe221_GGA6 & CTATAGCACCTTTCGGAGTG & ACCTACACCCTGATAAGCAAT & $157-177$ \\
\hline Fe232_GA6 & AAAGATGGAGTCGCAGAGT & СТCTCCAGAGATCTGAAGGTT & $179-191$ \\
\hline Fe250_GACGGC4 & CACACTCAAGGCTCACGTA & ACACGGACAGAAGATGAGAC & $164-200$ \\
\hline Fe264_AGGT4 & CATCCATCCTATCAGAGTTCA & GCCAAGAAAGTATCTGCATC & $156-168$ \\
\hline Fe268_TGGG3 & CTGTTAAGAGGAGGTGGAAGT & GCAAGTATCGTCCTGGTAATA & $167-182$ \\
\hline Fe273_AGAGGG3 & GTCTTCAGGTAGGTTCAGGTC & CTGCAACTTCTCCACCAC & $190-229$ \\
\hline Fe274_CGCTGT6 & CTAGGTGTATCCAGTGCAGAT & CTCACCTATAGGCAAGGTCAT & $141-256$ \\
\hline
\end{tabular}

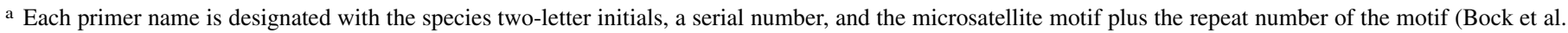
2016a). 
To test for deviation, the $\mathrm{H}$ for a population calculated from the allele frequencies was compared with the estimated $\mathrm{H}$ based on the number of alleles expected under $\mathrm{H}_{\mathrm{EQ}}$ (Cornuet and Luikart 1996). Populations that have experienced a bottleneck have greater than the expected $\mathrm{H}$ under $\mathrm{H}_{\mathrm{EQ}}\left(\mathrm{H}>\mathrm{H}_{\mathrm{EQ}}\right)$, whereas populations that have experienced a recent population expansion will have lower $\mathrm{H}$ than that expected under $\mathrm{H}_{\mathrm{EQ}}\left(\mathrm{H}<\mathrm{H}_{\mathrm{EQ}}\right)$, because the average number of alleles increases faster than the $\mathrm{H}$ until $\mathrm{H}_{\mathrm{EQ}}$ is attained (Nei et al. 1975). For each population, the tests were performed under the infinite allele model (IAM), the stepwise mutation model (SMM), and the two-phase mutation (TPM) model of evolution. The TPM was run using the default of $70 \%$ SMM and 30\% IAM. Deviation from $\mathrm{H}_{\mathrm{EQ}}$ (i.e., a significant number of loci with $\mathrm{H}$ excess or deficit) was determined using a sign test, a standardized difference test, and a Wilcoxon one-tailed test (Cornuet and Luikart 1996; Piry et al. 1999). The mode shift that describes allele frequencies in populations was also characterized (Piry et al. 1999).

A Mantel test was performed to explore the relationship between the $\log _{10}$-transformed geographic distance (logGD), due to heterogeneity of variance, and both gene flow between orchard populations $\left(N_{m}\right)$ and Nei's unbiased measure of genetic distance $(\mathrm{H})$ using the software Isolation by Distance V1.52 (Bohonak 2002). For the Mantel test, the test statistic $Z$ was calculated as $\Sigma_{I, j}$ $N m_{i j} \log \mathrm{GD}_{i j}$. The correlation was estimated as $r$ (Manly 1994) and the significance was assessed by comparing $r_{\text {actual }}$ to a distribution of $r$ scores obtained by randomizing the rows and columns of the matrix and assessing the one-tailed $P$ values using 1,000 permutations.

\section{RESULTS}

Genotypic and gene diversity among populations of $\boldsymbol{V}$. effusa in the United States. In total, 784 isolates was collected from 63 pecan trees in 11 orchards. The number of isolates from each orchard population ranged from 34 to 103 (Table 3). The 30 polymorphic microsatellites readily differentiated most isolates (Supplementary Fig. S1). The number of alleles per locus ranged from 3 for locus Fe097_AGGAGC3 to 51 for locus Fe050_CA6 (mean number of alleles $=14.4$ ). The percentages of polymorphic loci were high in all orchards and ranged from 96.7 (orchards designated MS and TX) to 100\% (all other orchards).
Based on all populations, 739 different MLGs were identified. For each population, the number of MLG detected (33 to 100) was highly dependent on population sample size $\left(R^{2}=0.99\right)$, and the clonal fraction was consistently small in all populations $(\leq 10.1 \%$ of isolates). Genotypic richness, measured as the expected number of MLG after rarefaction $(n=33)$, was very similar for all populations (31.8 to 33.9 MLG) (Table 3; Supplementary Fig. S2). Indices of genotypic diversity, which incorporate measures of both genotypic richness and abundance, indicated consistently high diversity in all populations: Shannon-Weiner's index $(\mathrm{H})$ ranged from $3.49(\mathrm{KS})$ to 4.59 (OK); Stoddart and Taylor's index $(\mathrm{G})$ ranged from 32.1 (KS) to $97.3(\mathrm{OK})$; and Simpson's index $(\lambda)$ ranged from 0.969 (GA-B) to 0.990 (OK). Evenness (E.5) was fairly uniform, and ranged from 0.912 (GA-B) to 0.994 (AL-F). $\mathrm{H}_{\text {exp }}$ ranged from 0.513 (LA) to $0.713(\mathrm{KS})$.

Of the haplotypes that were shared within and between orchards (43 clones in total), the majority were shared within the same tree in an orchard (27 of the 63 trees that were sampled had at least one clone), with clones being found in all 11 orchard populations. The most common clone was isolated four times from a single tree in the Texas orchard. Only two clones were shared between orchard populations.

Private alleles and linkage disequilibrium. Among the populations, the average number of alleles ranged from 5.1 in the FL and GA-T orchards to 9.0 in the OK orchard (Table 4). The mean number of private alleles was low in all cases, ranging from 0.033 for the population of $V$. effusa from the orchard in Florida to 1.333 for the population from Oklahoma (no other orchard had numbers of private alleles $>0.80)$. Gametic disequilibrium was tested with multilocus analysis using $I_{A}$ and $\bar{r}_{d}$ (Table 4). When using clonecorrected data, only the Kansas population was in equilibrium. All other orchard populations of $V$. effusa based on both the nonclonecorrected and clone-corrected data deviated from equilibrium $(P \leq$ $0.001)$. The number of pairs of loci not in equilibrium was variable but ranged from $6.21 \%(\mathrm{KS})$ to $58.16 \%$ of loci (AL-L). In all, 8 of the 11 populations had $<20 \%$ pairs of loci in disequilibrium.

Population structure and distribution of genetic variation. Nei's unbiased measure of genetic identity, which is a measure of the similarity among alleles that are the same between two populations, ranged from 0.418 (LA versus FL) to 0.964 (GA-B versus GA-T), indicating that populations shared a moderate to

TABLE 3. Statistics summarizing the populations of Venturia effusa and the genetic variation within those populations at the level of the pecan orchard in the southeastern United States

\begin{tabular}{|c|c|c|c|c|c|c|c|c|c|c|}
\hline Pop $^{a}$ & $N^{\mathrm{b}}$ & $\mathrm{MLG}^{\mathrm{c}}$ & $\mathrm{CF}(\%)^{\mathrm{d}}$ & $\mathrm{eMLG}^{\mathrm{e}}$ & $S E^{f}$ & $\mathrm{H}^{\mathrm{g}}$ & $\mathrm{G}^{\mathrm{h}}$ & $\lambda^{\mathrm{i}}$ & E. $5^{\mathrm{j}}$ & $\mathrm{H}_{\exp }{ }^{\mathrm{k}}$ \\
\hline AL-F & 93 & 92 & 1.1 & 33.9 & 0.338 & 4.52 & 91.0 & 0.989 & 0.994 & 0.594 \\
\hline AL-L & 91 & 83 & 8.8 & 32.8 & 0.977 & 4.38 & 76.0 & 0.987 & 0.948 & 0.633 \\
\hline GA-B & 63 & 59 & 6.3 & 32.5 & 0.992 & 4.03 & 51.5 & 0.981 & 0.912 & 0.557 \\
\hline $\mathrm{KS}$ & 34 & 33 & 2.9 & 33.0 & 0.000 & 3.49 & 32.1 & 0.969 & 0.983 & 0.713 \\
\hline LA & 68 & 66 & 2.9 & 33.5 & 0.603 & 4.18 & 64.2 & 0.984 & 0.983 & 0.513 \\
\hline MS & 89 & 80 & 10.1 & 32.6 & 1.041 & 4.34 & 72.7 & 0.986 & 0.944 & 0.590 \\
\hline FL & 52 & 50 & 3.8 & 33.2 & 0.688 & 3.90 & 48.3 & 0.979 & 0.979 & 0.570 \\
\hline $\mathrm{OK}$ & 103 & 100 & 2.9 & 33.7 & 0.530 & 4.59 & 97.3 & 0.990 & 0.984 & 0.674 \\
\hline GA-T & 45 & 44 & 2.2 & 33.4 & 0.496 & 3.78 & 43.1 & 0.977 & 0.987 & 0.564 \\
\hline $\mathrm{TX}$ & 93 & 86 & 7.5 & 32.9 & 0.985 & 4.41 & 76.5 & 0.987 & 0.926 & 0.620 \\
\hline IL & 53 & 48 & 9.4 & 31.8 & 1.065 & 3.83 & 43.2 & 0.977 & 0.937 & 0.682 \\
\hline Total $^{1}$ & 784 & 739 & 5.7 & 33.9 & 0.316 & 6.58 & 687.5 & 0.999 & 0.955 & 0.719 \\
\hline
\end{tabular}

a Population name (defined in Table 1).

b Number of isolates.

c Number of multilocus genotypes (MLG) observed.

d Clonal fraction.

e Number of expected MLG (eMLG) at the smallest sample size.

f Shannon-Wiener Index of MLG diversity (Shannon 2001).

g Stoddart and Taylor's index of MLG diversity (Stoddart and Taylor 1988).

h Standard error (SE) based on eMLG (Simpson 1949).

i Simpson's Index (Simpson 1949).

j Evenness. Pielou (1975); Ludwig and Reynolds (1988); Grünwald et al. (2003).

${ }^{k}$ Nei's unbiased measure of gene diversity (Nei 1978).

1 Total or average. 
substantial identity (Table 5). Nei's unbiased measure of genetic distance indicated that populations varied in their degree of relatedness from 0.037 (GA-B versus GA-T), which were separated by a relatively short genetic distance, to 0.873 (LA versus FL), which were separated by greater genetic distance. A pairwise comparison of the interpopulation genetic distances measured by $\phi_{\mathrm{PT}}$ showed a similar pattern and found that all pairwise comparisons were significantly different $(P \leq 0.001)$ based on 1,000 randomizations (Table 6).
The nearest-neighbor phylogenetic analysis based on 1,000 bootstrap values established that some populations were, indeed, more closely related than others (Fig. 2). In particular, populations GA-T, GA-B, and FL, all from locations at the eastern end of the range of the pathogen, were grouped together (node value $=100 \%$ ). Other clusters formed with slightly lower repeatability. Similarly, the PCoA based on Nei's unbiased measure of genetic distance indicated varying degrees of population separation according to principal component (PC)1 and PC2, which explained 64.7 and

TABLE 4. Measures of random mating among populations of Venturia effusa from different pecan orchards in the southeastern United States ${ }^{\mathrm{a}}$

\begin{tabular}{|c|c|c|c|c|c|c|c|c|c|}
\hline Pop $^{\mathrm{b}}$ & $N^{\mathrm{c}}$ & $\mathrm{MLG}^{\mathrm{d}}$ & Alleles & Private & $I_{A}{ }^{\mathrm{e}}$ & $I_{A} c c$ & $\bar{r}_{d}{ }^{\mathrm{f}}$ & $\bar{r}_{d} c c$ & $N d(\%)^{\mathrm{g}}$ \\
\hline AL-F & 93 & 92 & 6.233 & 0.133 & $0.672 *$ & $0.669 *$ & $0.0237 *$ & $0.0236^{*}$ & $80 / 435$ (18.39) \\
\hline AL-L & 91 & 83 & 6.500 & 0.200 & $1.611^{*}$ & $1.389 *$ & $0.0561 *$ & $0.0485^{*}$ & $253 / 435(58.16)$ \\
\hline GA-B & 63 & 59 & 5.433 & 0.167 & $1.100 *$ & $0.978 *$ & $0.0383 *$ & $0.0341^{*}$ & $51 / 435(11.72)$ \\
\hline $\mathrm{KS}$ & 34 & 33 & 7.167 & 0.800 & $0.272 *$ & $0.108 *$ & $0.0097 *$ & 0.0039 & $27 / 435(6.21)$ \\
\hline LA & 68 & 66 & 5.267 & 0.267 & $0.884 *$ & $0.848 *$ & $0.0316^{*}$ & $0.0305^{*}$ & $67 / 435(15.40)$ \\
\hline MS & 89 & 80 & 6.033 & 0.167 & $1.251 *$ & $1.227 *$ & $0.0450 *$ & $0.0442 *$ & $105 / 406(25.86)$ \\
\hline FL & 52 & 50 & 5.067 & 0.033 & $1.457^{*}$ & $1.341 *$ & $0.0506 *$ & $0.0466^{*}$ & $70 / 435$ (16.09) \\
\hline $\mathrm{OK}$ & 103 & 100 & 9.000 & 1.333 & $0.322 *$ & $0.274 *$ & $0.0114 *$ & $0.0097 *$ & $56 / 435$ (12.87) \\
\hline GA-T & 45 & 44 & 5.067 & 0.100 & $0.891 *$ & $0.821 *$ & $0.0312 *$ & $0.0288 *$ & $60 / 435(13.79)$ \\
\hline $\mathrm{TX}$ & 93 & 86 & 6.467 & 0.433 & $0.555^{*}$ & $0.463 *$ & $0.0200 *$ & $0.0167 *$ & $58 / 406(14.29)$ \\
\hline IL & 53 & 48 & 6.700 & 0.733 & $2.273^{*}$ & $1.606^{*}$ & $0.0810 *$ & $0.0573 *$ & $207 / 435$ (47.59) \\
\hline Total & 784 & 739 & $\ldots$ & $\ldots$ & $\ldots$ & $\ldots$ & $\ldots$ & $\ldots$ & $\ldots$ \\
\hline
\end{tabular}

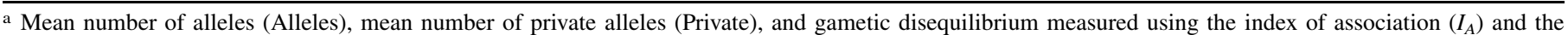
standardized index of association $\left(\bar{r}_{d}\right)$, for both the full data set and the clone-corrected (cc) data $\left(I_{A} c c\right.$ and $\left.\bar{r}_{d} c c\right)$. The $\bar{r}_{d}$ is a more robust measure, and less sensitive to the number of loci (Agapow and Burt 2001). Statistics were calculated based on 1,000 randomizations. Asterisks (*) indicate $P \leq 0.001$.

b Population name (defined in Table 1).

c Number of isolates.

d Number of multilocus genotypes (MLG) observed.

e Brown et al. (1980) and Smith et al. (1993).

f Agapow and Burt (2001).

$\mathrm{g}$ Pairs of loci not in equilibrium (\% pairs not in equilibrium).

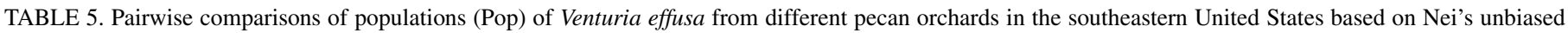
genetic identity (above diagonal) and Nei's unbiased genetic distance (below diagonal) ${ }^{\mathrm{a}}$

\begin{tabular}{|c|c|c|c|c|c|c|c|c|c|c|c|}
\hline Pop & AL-F & AL-L & GA-B & KS & LA & MS & FL & $\mathrm{OK}$ & GA-T & TX & IL \\
\hline AL-F & $\ldots$ & 0.855 & 0.595 & 0.823 & 0.692 & 0.859 & 0.570 & 0.758 & 0.619 & 0.719 & 0.786 \\
\hline AL-L & 0.157 & $\ldots$ & 0.771 & 0.877 & 0.626 & 0.738 & 0.740 & 0.826 & 0.794 & 0.746 & 0.812 \\
\hline GA-B & 0.518 & 0.260 & $\ldots$ & 0.640 & 0.487 & 0.563 & 0.930 & 0.631 & 0.964 & 0.543 & 0.618 \\
\hline $\mathrm{KS}$ & 0.195 & 0.131 & 0.446 & $\ldots$ & 0.708 & 0.802 & 0.625 & 0.916 & 0.662 & 0.772 & 0.885 \\
\hline LA & 0.368 & 0.469 & 0.719 & 0.346 & $\ldots$ & 0.731 & 0.418 & 0.625 & 0.443 & 0.591 & 0.664 \\
\hline MS & 0.151 & 0.304 & 0.574 & 0.220 & 0.314 & $\ldots$ & 0.555 & 0.723 & 0.569 & 0.671 & 0.756 \\
\hline FL & 0.563 & 0.301 & 0.073 & 0.471 & 0.873 & 0.588 & $\ldots$ & 0.638 & 0.930 & 0.534 & 0.622 \\
\hline $\mathrm{OK}$ & 0.277 & 0.192 & 0.460 & 0.087 & 0.470 & 0.324 & 0.450 & $\ldots$ & 0.659 & 0.714 & 0.817 \\
\hline GA-T & 0.479 & 0.231 & 0.037 & 0.413 & 0.814 & 0.564 & 0.072 & 0.418 & $\ldots$ & 0.584 & 0.626 \\
\hline $\mathrm{TX}$ & 0.329 & 0.293 & 0.610 & 0.258 & 0.526 & 0.399 & 0.626 & 0.337 & 0.538 & $\ldots$ & 0.737 \\
\hline IL & 0.240 & 0.208 & 0.481 & 0.122 & 0.409 & 0.279 & 0.475 & 0.202 & 0.468 & 0.305 & $\ldots$ \\
\hline
\end{tabular}

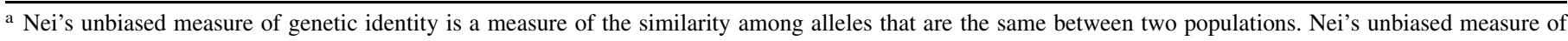
genetic distance evaluates genetic differentiation between populations (Nei 1978). All calculations were performed in GenAlEx V6.5 (Peakall and Smouse 2012).

TABLE 6. Pairwise comparisons of populations (Pop) of Venturia effusa from different pecan orchards in the southeastern United States based on $\phi_{\mathrm{PT}}$ values ${ }^{\mathrm{a}}$

\begin{tabular}{|c|c|c|c|c|c|c|c|c|c|c|c|}
\hline Pop & AL-F & AL-L & GA-B & $\mathrm{KS}$ & LA & MS & FL & OK & GA-T & $\mathrm{TX}$ & IL \\
\hline AL-F & $\ldots$ & 0.001 & 0.001 & 0.001 & 0.001 & 0.001 & 0.001 & 0.001 & 0.001 & 0.001 & 0.001 \\
\hline AL-L & 0.084 & $\ldots$ & 0.001 & 0.001 & 0.001 & 0.001 & 0.001 & 0.001 & 0.001 & 0.001 & 0.001 \\
\hline GA-B & 0.228 & 0.134 & $\ldots$ & 0.001 & 0.001 & 0.001 & 0.001 & 0.001 & 0.001 & 0.001 & 0.001 \\
\hline $\mathrm{KS}$ & 0.097 & 0.060 & 0.182 & $\ldots$ & 0.001 & 0.001 & 0.001 & 0.001 & 0.001 & 0.001 & 0.001 \\
\hline LA & 0.200 & 0.218 & 0.311 & 0.178 & $\ldots$ & 0.001 & 0.001 & 0.001 & 0.001 & 0.001 & 0.001 \\
\hline MS & 0.088 & 0.141 & 0.244 & 0.106 & 0.181 & $\ldots$ & 0.001 & 0.001 & 0.001 & 0.001 & 0.001 \\
\hline FL & 0.233 & 0.143 & 0.052 & 0.179 & 0.333 & 0.241 & $\ldots$ & 0.001 & 0.001 & 0.001 & 0.001 \\
\hline $\mathrm{OK}$ & 0.124 & 0.083 & 0.185 & 0.037 & 0.206 & 0.139 & 0.176 & $\ldots$ & 0.001 & 0.001 & 0.001 \\
\hline GA-T & 0.213 & 0.118 & 0.027 & 0.166 & 0.326 & 0.237 & 0.049 & 0.168 & $\ldots$ & 0.001 & 0.001 \\
\hline $\mathrm{TX}$ & 0.154 & 0.130 & 0.240 & 0.109 & 0.239 & 0.176 & 0.237 & 0.135 & 0.219 & $\ldots$ & 0.001 \\
\hline IL & 0.113 & 0.089 & 0.195 & 0.047 & 0.196 & 0.127 & 0.185 & 0.079 & 0.184 & 0.126 & $\ldots$ \\
\hline
\end{tabular}

a $\phi_{\mathrm{PT}}$ is analogous to $\mathrm{F}_{\mathrm{st}}$ (Wright 1969) and is based on genetic distance estimates. It assumes a stepwise mutation model and measures the distribution of variation and differential connectivity among populations (Excoffier et al. 1992). $\phi_{\mathrm{PT}}$ values appear below the diagonal and probability $(P$ ) of a difference between the pairs of populations, based on 1,000 permutations, is shown above the diagonal. All calculations were performed in GenAlEx V6.5 (Peakall and Smouse 2012). 
$16.2 \%$ of the variance, respectively (Supplementary Fig. 3A). At the tree level, there was orchard-specific grouping but also substantial overlap among some orchard populations (Supplementary Fig. 3B). The orchard sampled in Louisiana was particularly unique and, although other groups did separate (for example, GA-B, GA-T, and FL), it was not as clear-cut, and PC1 and PC2 explained less of the variation (42.9 and 13.3\%, respectively).

Applying a Bayesian method to explore clustering using Structure indicated that the populations were discernable as eight clusters (Fig. 3A and $\mathrm{B}$ ); $\operatorname{Pr}(X / K)$ supported seven clusters but $\Delta K$, considered a more robust estimator, supported a cluster assignment of eight. Population cluster assignment and admixture for each isolate for $K=6$ to 11 demonstrated the limited cluster affinity at all $K$ (Fig. 3). Thus, at $K=8$, GA-T, GA-B, and FL shared similar admixture (predominantly pale-blue isolates), whereas the remaining eight populations were differentiated as independent clusters. There was admixture among isolates in all populations. The minimum spanning network also indicated that isolates from a single population tended to be located mostly in one or two of the clusters at $K=8$ (Fig. 4). For example, isolates from populations FL, GA-B, and GA-T were most frequently located in the pale and dark green clusters, whereas those from TX were most often in the pink cluster. However, all clusters contained isolates from several source populations but not all orchard populations were represented in each cluster.

Some population differentiation of $V$. effusa among orchards within the southeastern region of the United States was supported by the hierarchical AMOVA (Table 7). The AMOVA showed that, although a majority of the genetic variability $(81 \%)$ occurred at the scale of the individual tree $\left(\phi_{\mathrm{PL}}=0.188, P \leq 0.001\right)$, a smaller proportion of the variability occurred between orchards $\left(16 \%, \phi_{\mathrm{PO}}=\right.$ $0.158, P \leq 0.001)$ but only a very small amount between trees within orchards $\left(3 \%, \phi_{\mathrm{PT}}=0.035, P \leq 0.001\right)$. This is indicative of some limited population differentiation in $V$. effusa in the southeastern United States.

Recent population dynamics, migration, and the effect of geographic distance. The microsatellite markers in 8 of the 11 populations followed a SMM (Table 8). However, the microsatellite markers from populations AL-L, KS, and IL followed an IAM. Based on the Wilcoxon one-tailed test, those populations of $V$. effusa with a predominantly SMM evolution had a significant deficit of $\mathrm{H}$ (that is, observed $\mathrm{H}$ was less than that expected when the population is at mutation-drift equilibrium $\left.\left(\mathrm{H}_{\mathrm{EQ}}\right)\right]$. This suggests that these populations have undergone a recent expansion. In contrast, those populations assuming predominantly IAM evolution (AL-L, KS, and IL) had a predominance of excess in $\mathrm{H}$, which suggests these populations may have experienced a recent bottleneck. Both the sign and standardized difference test gave similar results. However, overall, allele frequencies in all populations had an L-shaped distribution, which indicated mutation drift equilibrium for many comparisons.

The estimates of $\mathrm{Nm}$ (which approximates numbers of migrants exchanged between two populations per generation) indicated that there are frequent migrations ( $>1$ to approximately 18) among populations of V. effusa in the southeastern United States (Table 9). The greatest number of migrants $(\mathrm{Nm}=17.930)$ was between the two orchard populations in Georgia.

The Mantel test indicated that Nei's unbiased measure of genetic distance was positively associated with $\log$ physical distance $(Z=11.9$, $r=0.559, P=0.001)$ (Fig. 5A); that is, more distant populations tended to be less closely related. In contrast, $\mathrm{Nm}$ (the estimated mean number of migrants of $V$. effusa across loci per generation between each pair of populations) had a negative association with log-transformed physical distance $(Z=11.2, r=0.434, P=0.002)$ (Fig. 5B). That is, there were fewer migrants between more distant populations.

\section{DISCUSSION}

The pathogen $V$. effusa exhibited moderate to high gene and genotypic diversity in all of the populations that were sampled.
Not only did populations exhibit substantial genetic diversity, they also had similar evenness, with all populations showing comparable and high abundance of genotypes $(E .5>0.912)$. Indeed, the results corroborate the findings of an earlier study using dominant genetic markers that found substantial diversity among populations of $V$. effusa in orchards in the southeastern United States (Bock et al. 2014b). However, due to the codominant nature of microsatellites, they allow a more sensitive analysis of population structure, gene flow, and population changes compared with dominant molecular markers such as random amplified polymorphic DNA or universally primed (UP)-PCR. In particular, microsatellites are characterized by elevated mutation rates compared with gene-coding DNA (Dettman and Taylor 2004) and, thus, provide an opportunity to observe short-term changes in populations that might occur for various reasons (Linde et al. 2009, 2010; Spencer et al. 2000).

Although the sample size was smaller in the dominant marker study ( $n=185$ ) (Bock et al. 2014b) compared with the current study $(n=784)$, both studies found very low clonality at the spatial scales sampled. There was congruence between the two studies in the proportion of unique MLG: based on 5 UP-PCR primers, $95.4 \%$ of isolates were unique MLG whereas, based on 30 microsatellite primers, $94.3 \%$ of isolates were unique MLG. As a result, clone correction had only slight effects on analyses.

Spatial structure was readily determined among the 11 populations. Nei's unbiased measure of genetic distance indicated that all populations could be differentiated from one another, and the pairwise analysis of population $\phi_{\mathrm{PT}}$ values confirmed significant differentiation among all of the populations. Similar analysis by Bock et al. (2014b) using UP-PCR also found significant pairwise population differentiation. This was further visualized and verified based on the PCoA analysis at both the orchard and the tree-withinorchard level: populations were clearly grouped, although there was also some overlap. Furthermore, the nearest-neighbor analysis found that each population could be differentiated with bootstrap values of 52.9 to $100.0 \%$. These observations of population subdivision were supported by the clustering identified using Bayesian analysis (using the program Structure), which detected eight clusters based on $\Delta K$. However, using the same analysis

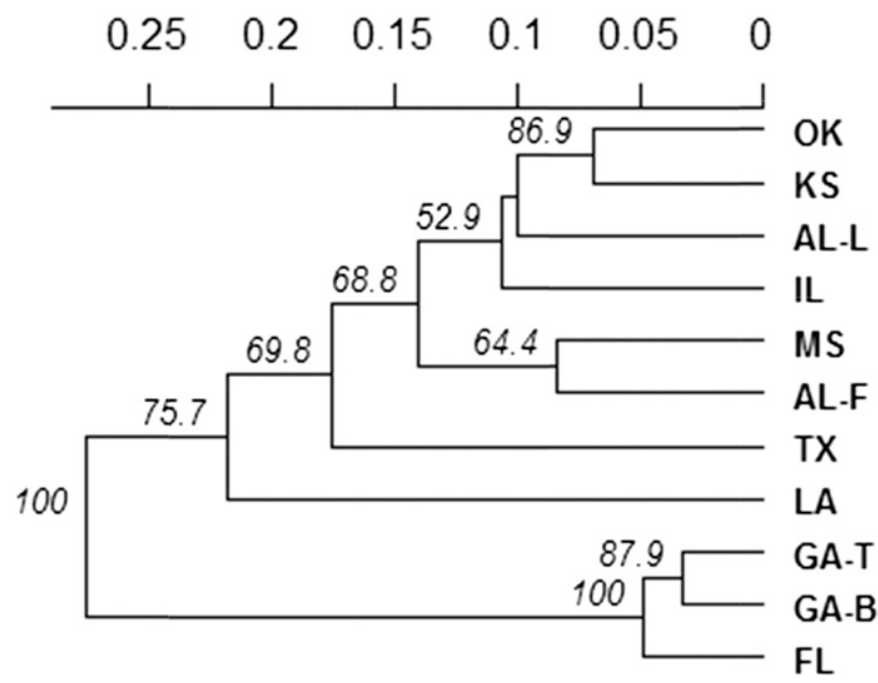

Fig. 2. Phylogenetic tree of populations of Venturia effusa from different pecan orchards in the southeastern region of the United States based on Nei's measure of genetic distance and using the nearest neighbor-joining method. Values at the nodes of the branches represent the percentage of times that separation occurred based on 1,000 bootstrap values. Dendrogram was calculated in $r$ using the poppr package (Kamvar et al. 2014). 
applied to data from the previous UP-PCR study, there was little evidence of structure based on a plot of $\Delta K$ against $K=1$ to 11 , although the plot of $\operatorname{Pr}(X / K)$, on which clustering is considered less easy to detect (Evanno et al. 2005), suggested a peak between 6 and 8 (Bock et al. 2014b). Finally, the minimum spanning tree of all 784 isolates also demonstrated discernable structure based on a comparison of isolates at $K=8$; group membership was evident from the pronounced clustering of isolates, with emphasis on their source populations. Interestingly, those isolates from Texas, Louisiana, Kansas, Oklahoma, Florida, Georgia (Byron), and Georgia (Tifton) tended to be the more peripheral, whereas those from Alabama, Mississippi, and Illinois tended to be clustered around the hub of the tree, perhaps indicating that these are more ancestral populations.

The isolates of $V$. effusa all originated from six trees (except the Kansas isolates, which were from three trees) in individual orchards separated from each other by 111 to $1,317 \mathrm{~km}$. Evidence for some geographic separation among populations was confirmed by the Mantel tests, whereby genetic distance among populations had a positive association with geographic distance (the further apart a pair of populations, the greater the genetic separation). Earlier data generated based on UP-PCR studies with smaller sample sizes was inconsistent (Bock et al. 2014a,b). Furthermore, although an approximation, the pairwise $\mathrm{Nm}$ values which indicate the number of migrants of $V$. effusa across loci per generation between each pair of populations suggested evidence of migration among orchard populations that was inversely related to distance.

The AMOVA found that $81 \%$ of the genetic diversity could be accounted for at the spatial scale of a single tree (i.e., the scale of tens of meters). This is very similar to the value observed using UPPCR, which was $82.6 \%$, based on a smaller sample size (Bock et al. 2014b). Very little additional diversity was found between trees
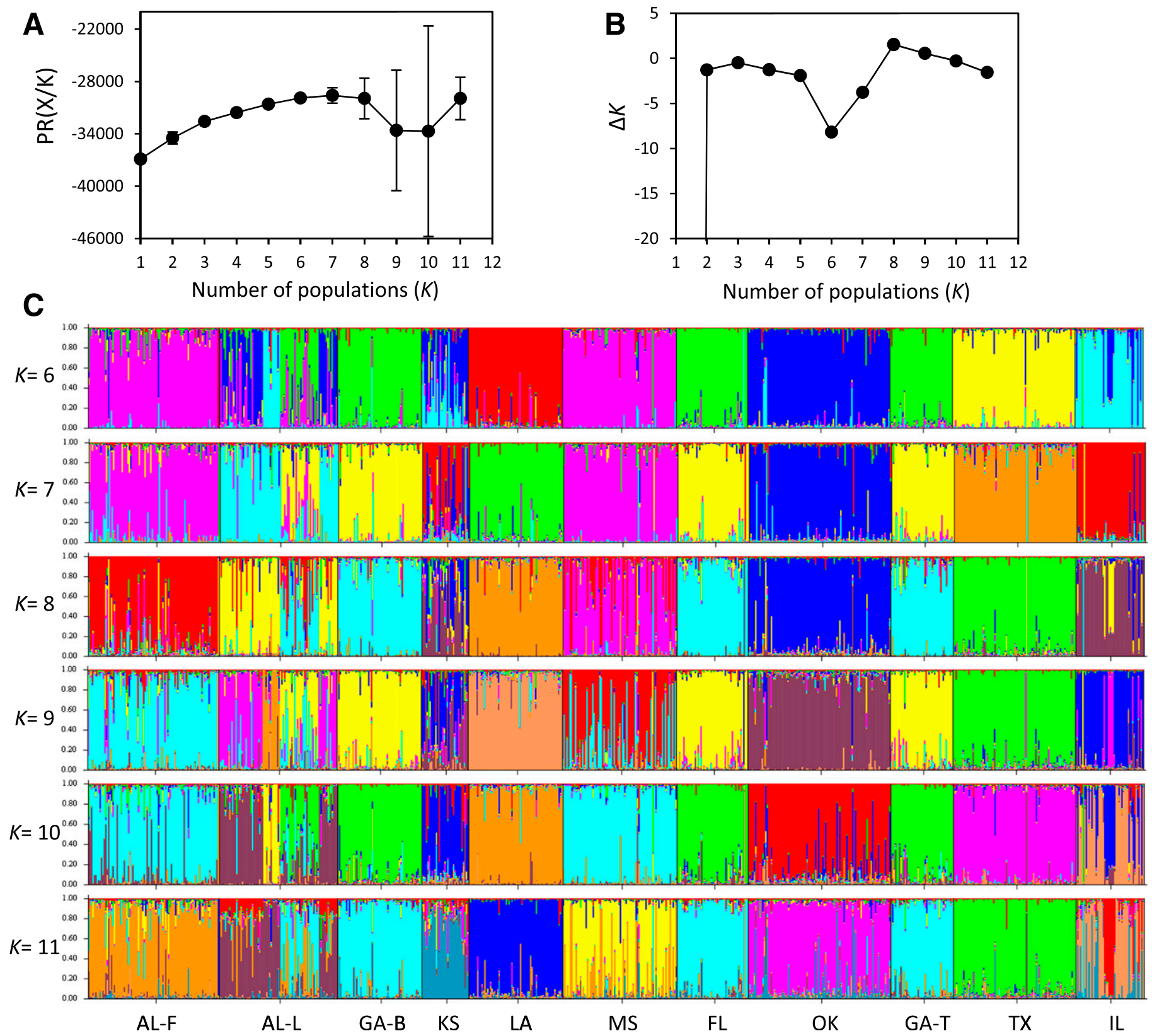

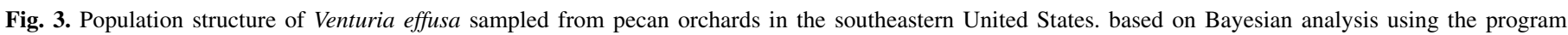

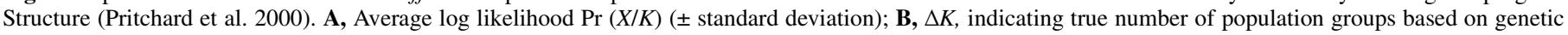

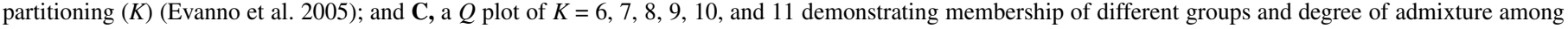
populations (assumed population identity). 


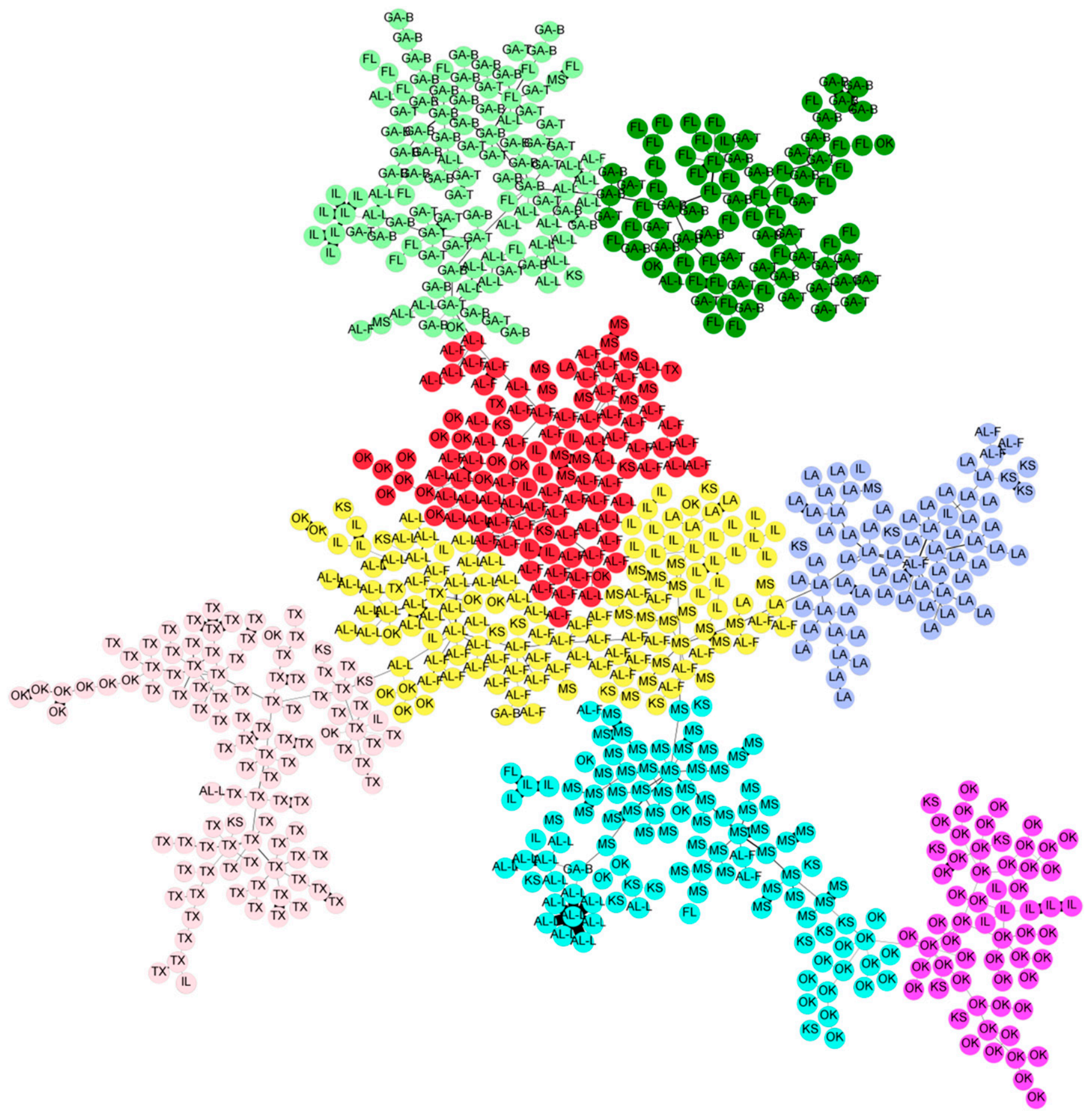

Fig. 4. Minimum spanning tree of 784 isolates of Venturia effusa (cause of pecan scab) collected from 11 orchards of pecan across the southeastern United States. The source population of each isolate in each of the eight defined clusters is indicated. The minimum spanning network was based on node and edge data generated by Arlequin V3.5 (Excoffier et al. 2005), and the network analysis was performed in Gephi V0.9.1 (Bastian et al. 2009) using the Atlas and Atlas 2 algorithms for separation of nodes and edges. For analysis, eight clusters were assumed based on the results of the earlier Bayesian analysis from Structure V2.3.4 (Pritchard et al. 2000). Due to limitations of space, nodes of only one size were used; thus, there is no representation of clonal individuals in this graphic.

TABLE 7. Hierarchical analysis of molecular variance (AMOVA) using clone-corrected data of the population structure of Venturia effusa collected from pecan orchards and trees within orchards in the southeastern United States ${ }^{\mathrm{a}}$

\begin{tabular}{|c|c|c|c|c|c|c|c|}
\hline Source & Df & SS & MS & Est. var. & $\%$ & FI & $P$ \\
\hline Between orchards & 10 & $1,286.2$ & 128.6 & 1.74 & 16 & $\phi_{\mathrm{PO}}=0.158$ & 0.001 \\
\hline Between trees within orchards & 52 & 656.9 & 12.6 & 0.32 & 3 & $\phi_{\mathrm{PT}}=0.035$ & 0.001 \\
\hline Within trees & 678 & $6,036.2$ & 8.9 & 8.90 & 81 & $\dot{\phi}_{\mathrm{PL}}=0.188$ & 0.001 \\
\hline
\end{tabular}

a AMOVA was performed using GenAlEx V6.5 (Peakall and Smouse 2012). Df $=$ degrees of freedom, SS $=$ sum of squares, Est. var. $=$ estimated variance, $\%=$ percentage of total variance, $\mathrm{FI}=$ fixation indices (genetic differentiation, where $\phi_{\mathrm{PO}}=$ between orchard population differentiation, $\phi_{\mathrm{PT}}=$ between tree population differentiation within orchards, and $\phi_{\mathrm{PL}}=$ among isolates from different leaflets within a tree population), and $P=$ probability. 
within orchards (3\%), although there was more at the scale of the individual orchards (16\%). Thus, the populations of the pathogen appear to share genetic material freely or possibly have a common ancestral founder population in the recent past.

In general, these observations on population structure and genetic diversity based on codominant markers resemble those of other

TABLE 8. Comparison of the observed gene diversity $(\mathrm{H})$ and the expected gene diversity at mutation-drift equilibrium $\left(\mathrm{H}_{\mathrm{EQ}}\right)$ based on the observed number of alleles with the infinite allele model (IAM), the two-phase model (TPM), and the step-wise mutation model (SMM) of evolution

\begin{tabular}{lrllll}
\hline & & & \multicolumn{3}{c}{ Deficiency or excess ${ }^{\mathrm{a}}$} \\
\cline { 5 - 6 } Population & $N^{\mathrm{b}}$ & \multicolumn{1}{c}{ Mutation model } & IAM & TPM & \multicolumn{1}{c}{ SMM } \\
\hline AL-F & 92 & SMM $(P=0.00003)$ & $9 / 21^{*}$ & $16 / 14$ & $25 / 5^{* * *}$ \\
AL-L & 83 & IAM $(P=0.00101)$ & $8 / 22^{* *}$ & $13 / 17$ & $18 / 12^{* *}$ \\
GA-B & 59 & SMM $(P=0.00030)$ & $14 / 16$ & $18 / 12$ & $22 / 8^{* *}$ \\
KS & 33 & IAM $(P=0.00310)$ & $10 / 20^{* *}$ & $12 / 18$ & $21 / 9^{* *}$ \\
LA & 66 & SMM $(P=0.00001)$ & $13 / 17$ & $19 / 11^{*}$ & $23 / 7^{* * *}$ \\
MS & 80 & SMM $(P=0.00205)$ & $10 / 19$ & $14 / 15$ & $21 / 8^{* *}$ \\
FL & 50 & SMM $(P=0.00873)$ & $10 / 20^{*}$ & $16 / 14$ & $19 / 11^{* *}$ \\
OK & 100 & SMM $(P=0.00001)$ & $10 / 20^{*}$ & $20 / 10^{*}$ & $24 / 6^{* * *}$ \\
GA-T & 44 & SMM $(P=0.00497)$ & $12 / 18$ & $15 / 15$ & $19 / 11^{* *}$ \\
TX & 86 & SMM $(P=0.00070)$ & $8 / 12^{* *}$ & $16 / 13$ & $20 / 9^{* *}$ \\
IL & 48 & IAM $(P=0.00019)$ & $5 / 25^{* *}$ & $7 / 23$ & $16 / 14$ \\
\hline
\end{tabular}

a Deficiency or excess indicates the number of loci showing a deficit or excess of gene diversity. Probability of deviation from mutation-drift equilibrium $\left(\mathrm{H}>\mathrm{H}_{\mathrm{EQ}}\right)$ was assessed using a Wilcoxon one-tailed test and a sign test (Cornuet and Luikart 1996). The frequency distribution for all alleles form each population was L-shaped. Asterisks *, **, and *** indicate $P \leq 0.05$, 0.01 , and 0.0001 , respectively.

b Number of isolates. well-characterized ascomycete pathogens, including $V$. inaequalis (Gladieux et al. 2010; Tenzer et al. 1999; Xu et al. 2013), Z. triticii (Linde et al. 2002; McDonald et al. 1995), R. commune (Linde et al. 2009; McDonald et al. 1999; Salamati et al. 2000), and A. brassicicola (Linde et al. 2010). Most often in each of these studies, there was a moderate to low clonal fraction, substantial genetic diversity, and much of that diversity could be found at a small spatial scale. However, only in some of these pathogens is a sexual stage characterized. No sexual stage has been identified for $R$. commune or A. brassicicola, although the mating type genes are in equilibrium (Linde et al. 2003, 2010). Recent findings by C. A. Young and N. D. Charlton (personal communication) suggest that the mating types of $V$. effusa are in equilibrium. We found linkage disequilibrium in all but one of the populations (KS) that we sampled. Nonrandom associations among alleles and loci observed in the remaining 10 populations might be due to a number of causes, including population structure (particularly isolated populations because, in some areas, there may be several kilometers between orchards or groups of orchards); in addition, nonrandom mating, linkage, asexual reproduction, or genetic drift can occur in founder populations or small populations (Crow and Kimura 1970; Taylor et al. 1999) and lead to linkage disequilibrium. It should also be noted that, with $R$. commune, linkage disequilibrium was the norm in all but 2 of the 27 field populations sampled (Linde et al. 2009), despite the mating types being in equilibrium (Linde et al. 2003).

Assuming the SMM, there is a deficit of $\mathrm{H}$ compared with the number of alleles present in 8 of the 11 populations, indicating that these populations of $V$. effusa have undergone a recent expansion or possibly been the recipients of rare alleles from immigrants (Cornuet and Luikart 1996; Luikart and Cornuet 1998). The

TABLE 9. Migration ( $\mathrm{Nm}$ ) values among populations of Venturia effusa collected from pecan orchards and trees within orchards in the southeastern United States ${ }^{\mathrm{a}}$

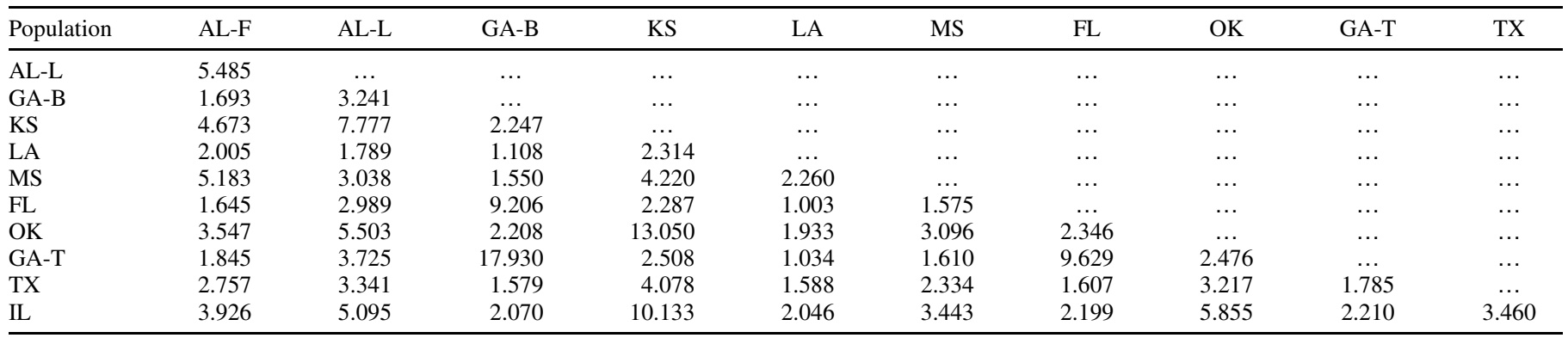

${ }^{a} \mathrm{Nm}$ values are considered numbers of migrants exchanged between the two populations per generation (Wright 1969). Analysis performed using GenAlEx V6.5 (Peakall and Smouse 2012).
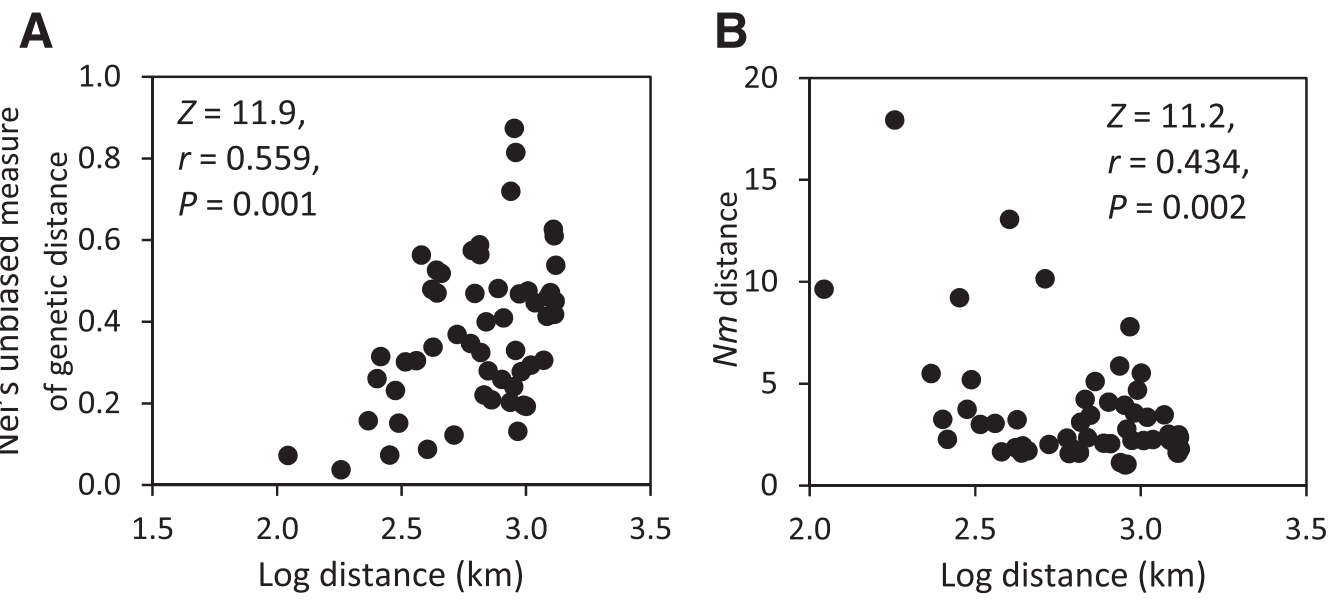

Fig. 5. Mantel tests between A, Nei's (1978) unbiased measure of genetic distance between each pair of populations of Venturia effusa and B, estimated number of migrants of $V$. effusa averaged across loci per generation ( $\mathrm{Nm}$, based on $\phi_{\mathrm{PT}}$ values) between each pair of populations and the logarithm of physical distance between each pair of populations. All calculations were performed using Isolation by Distance V1.52 (Bohonak 2002). 
populations AL-L, KS, and IL had a lower number of alleles than expected given their genetic diversity (i.e., an excess of $\mathrm{H}$ ) based on the IAM, which indicates a recent population bottleneck (although AL-L and KS also had significant excess under the SMM). Overall, these results are consistent with historical population expansion. Pecan production in the United States expanded in the late 19th to early 20th century (Worley 2002), with widespread cultivation of susceptible cultivars in the southeastern region. The pathogen is reported to have spread rapidly to this expanded host distribution (Demaree and Cole 1929). Analysis performed by Bottleneck detects only recent bottlenecks or population expansions occurring in the last \pm 100 years (Cornuet and Luikart 1996; Luikart and Cornuet 1998). Thus, populations of pecan may bear some resemblance to those of $A$. brassicicola on Cakile in southeastern Australia (Linde et al. 2010), which have undergone recent expansion and have some degree of geographical isolation. Also, it is worth noting that populations of $V$. inaequalis on apple in Eurasia demonstrated a preponderance of SMM (Gladieux et al. 2010), although it was speculated that this might be due not only to the recent, widespread domestication of apple but perhaps also to effects of climate change during the Pleistocene. Perhaps similar climatic effects have affected the populations of $V$. effusa in the southern United States. The native range of pecan is the watershed of the Mississippi (Worley 2002). Although pecan was spread widely in the southern United States by colonists prior to and after the 1776 American revolution, large-scale production of grafted, monotypic cultivars were planted relatively recently, in the late 19 th and early 20th centuries. Prior to that, pecan production was less intense and based on native seedlings, which were genetically diverse and exhibited a wide range of scab susceptibility (Bock et al. 2016d). Indeed, it was only in the early part of the 20th century that $V$. effusa became a pathogen of economic concern on pecan (Demaree and Cole 1929). The pathogen was first identified on mockernut (Carya alba $=$ C. tomentosa) in 1882, in Illinois (Winter 1885), and was observed on pecan in 1888 in Louisiana (Ellis and Everhart 1888). Other hosts reported are rare but include C. aquatica, C. cordiformis (= C. amara), C. glabra, and C. ovata (Schubert et al. 2003). These Carya spp. are native to the southeastern United States but are not cultivated; thus, their distribution is mostly very scattered. At this time, there is no evidence among isolates of $V$. effusa for host specificity for species of Carya. Demaree and Cole (1929) reported that pecan scab appeared to spread northward from the pecan belt on different varieties at different times. Thus, populations of $V$. effusa in nonnative areas might have been founded relatively recently in the last \pm 120 years. The pathogen can overwinter asexually in the previous seasons' lesions on shoots (Demaree 1924) and, if the recently identified sexual stage occurs sufficiently often in nature, there would be a basis for maintaining and transferring genetic diversity in the field. Georgia is the single largest producer of pecan (NASS 2015), and scabsusceptible cultivars are widely grown (Wells 2014). In areas where orchards are contiguous, populations of $V$. effusa may have a greater chance for homogeneity. The two populations from Georgia and that from Florida were among the closest geographically and were the three most closely related populations genetically (and were also furthest from the native range of the host).

Conidia have been demonstrated as important during scab epidemics, especially given the polycyclic nature of the pathogen throughout the growing season (Demaree 1924; Gottwald and Bertrand 1982; Latham 1982). The low incidence of clonality among isolates of $V$. effus $a$ observed in this study, and equilibrium of mating types, are evidence that the sexual stage (observed in-vitro) (C. A. Young and N. D. Charlton, personal communication) likely occurs frequently enough to maintain equilibrium of mating types. However, there is a possibility that a parasexual cycle (Pontecorvo cycle or asexual genetic exchange) (Pontecorvo 1956) occurs in populations of $V$. effusa, as has been demonstrated in $R$. commune (Forgan et al. 2007). The characteristics of the population genetic structure and diversity we observed for $V$. effusa is similar to that described for $R$. commune, for which mating type genes are also in equilibrium but for which no sexual stage has yet been identified. However, it seems unlikely that the high level of genetic diversity observed in $R$. commune (or, for that matter, in V. effusa) can be explained without the occurrence of sexual recombination (Linde et al. 2009).

Unlike many crops now grown worldwide (for example, wheat and barley, which have been spread widely over several centuries), C. illinoinensis originates from a relatively small area encompassing the Mississippi river watershed and a few close, surrounding locations in North America (United States and Mexico), and has only been cultivated more widely in the last approximately 120 years (Grauke et al. 2011, 2016). Like apple, pecan has a more fragmented distribution in space, comprising many cultivars, compared with most cereal agrosystems, which may limit propagation and dispersal of pathogens in these orchard crops (Gladieux et al. 2010). More recently, pecan has been cultivated in areas of South America, South Africa, Australia, Europe, and Asia. Epidemics of scab are known to be an issue, particularly in parts of South America (Kobayashi 1984; Mantz et al. 2009; Mendes et al. 1998), South Africa (DAFF 2000), and New Zealand (Pennycook et al. 1989). However, we have no information on the genetic characteristics of these populations of scab, which were likely imported along with the host, although this is characterized for other exotic tree pathogens (Groenewald et al. 2007; Hirst et al. 1999). How might they compare genetically to those from the North American populations? If they exist, how profound are founder effects? In addition to management of the disease in the field, this information may have ramifications for phytosanitary regulation.

Knowledge of plant pathogen population biology is important for management of the disease (McDonald and Linde 2002; McDonald and Mundt 2016): (i) understanding of the population biology of a disease can help clarify the origins of the pathogen in relation to the search for resistant germplasm, (ii) information on the genetic diversity in relation to population structure can clarify the evolutionary potential, (iii) knowledge of gene flow can provide valuable information on how best to impose a management strategy (local to regional), and (iv) information on adaptation potential of the pathogen to specific environments, including fungicide use can inform on how best to impose these management practices to minimize the risk of adaption. Very little has been characterized regarding the population structure and genetics of the pecan scab pathogen. The information presented and future research on the occurrence and epidemiological role of the sexual stage should aid in characterizing and understanding the population biology of V. effusa, and provide a basis for how best to apply both traditional and biotechnology-based approaches for establishing effective management of this pathogen to minimize its impact on pecan.

\section{ACKNOWLEDGMENTS}

We thank M. Zhang, W. Evans, N. Yadav, S. de Vos, B. Rawls, G. Moreland, and T. Endalew for their input and technical help; several growers and colleagues in different states who provided support in the process of collecting isolates; and B. McDonald, ETH-Zurich, for valuable comments and discussion at various stages during the study. The research was supported by the United States Department of AgricultureAgricultural Research Service through Current Research Information System project 6606-21220-012-00D. This article reports the results of research only. Mention of a trademark or proprietary product is solely for the purpose of providing specific information and does not constitute a guarantee or warranty of the product by the U.S. Department of Agriculture and does not imply its approval to the exclusion of other products that may also be suitable.

\section{LITERATURE CITED}

Agapow, P.-M., and Burt, A. 2001. Indices of multilocus linkage disequilibrium. Mol. Ecol. 1:101-102. 
Bastian, M., Heymann, S., and Jacomy, M. 2009. Gephi: An open source software for exploring and manipulating networks. Online publication. International AAAI Conference on Weblogs and Social Media. https://gephi.org/

Bock, C. H., Thrall, P. H., and Burdon, J. J. 2005. Genetic structure of populations of Alternaria brassicicola suggests the occurrence of sexual recombination. Mycol. Res. 109:227-236.

Bock, C. H., Brenneman, T. B., Wood, B. W., and Stevenson, K. L. Challenges of managing disease in tall orchard trees-Pecan scab, a case study. CAB Reviews. (in press)

Bock, C. H., Chen, C., Yu, F., Stevenson, K. L., Arias, R. S., and Wood, B. W. 2016a. Characterization of microsatellites in Fusicladium effusum, cause of pecan scab. For. Pathol. 46:600-609.

Bock, C. H., Chen, C., Yu, F., Stevenson, K. L., and Wood, B. W. 2016b. Draft genome sequence of Fusicladium effusum, cause of pecan scab. Stand. Genomic Sci. 11:36.

Bock, C. H., Endalew, T. T., Biswas, B. K., Yadav, A. K., Sitther, V., Hotchkiss, M. W., Stevenson, K. L., and Wood, B. W. 2014a. A comparison of UP-PCR and RAPD markers to study genetic diversity of the pecan scab fungus (Fusicladium effusum G. Winter). For. Pathol. 44:266-275.

Bock, C. H., Grauke, L. J., Conner, P., Burrell, S. L., Hotchkiss, M. W., Boykin, D., and Wood, B. W. 2016d. Scab susceptibility of a provenance collection of pecan in three different seasons in the southeastern USA. Plant Dis. 100:1937-1945.

Bock, C. H., Stevenson, K. L., Arias, R. S., and Wood, B. W. 2014b. Genetic diversity and population structure of Fusicladium effusum on pecan in the U.S.A. Plant Dis. 98:916-923.

Bock, C. H., Thrall, P. H., and Burdon, J. J. 2005. Genetic structure of populations of Alternaria brassicicola suggests the occurrence of sexual recombination. Mycol. Res. 109:227-236.

Bohonak, A. J. 2002. IBD (Isolation by Distance): A program for analyses of isolation by distance. J. Hered. 93:153-154.

Brown, A. H. D., Feldman, M. W., and Nevo, E. 1980. Multilocus structure of natural populations of Hordeum spontaneum. Genetics 96:523-536.

Conner, P. J., and Stevenson, K. L. 2004. Pathogenic variation of Cladosporium caryigenum isolates and corresponding differential resistance in pecan. HortScience 39:553-557.

Cornuet, J. M., and Luikart, G. 1996. Description and power analysis of two tests for detecting recent population bottlenecks from allele frequency data. Genetics 144:2001-2014.

Crow, J. F., and Kimura, M. 1970. An Introduction to Population Genetics Theory. Harper and Row, New York.

DAFF. 2000. Cultivating Pecan Nuts. Online publication. Department of Agriculture, Fisheries and Food, National Department of Agriculture, Pretoria, South Africa. http://www.daff.gov.za/docs/Infopaks/pecan.htm

Demaree, J. B. 1924. Pecan scab with special reference to sources of the early spring infections. J. Agric. Res. 28:321-333.

Demaree, J. B., and Cole, J. R. 1929. Behavior of Cladosporium effusum (Wint.) Demaree on some varieties of pecan. J. Agric. Res. 38:363-370.

Dettman, J. R., and Taylor, J. W. 2004. Mutation and evolution of microsatellite loci in Neurospora. Genetics 168:1231-1248.

Ellis, J. B., and Everhart, B. M. 1888. New species of fungi from various localities. J. Mycol. 4:121-124.

Ellsworth, D. L., Rittenhouse, K. D., and Honeycutt, R. L. 1993. Artifactual variation in randomly amplified polymorphic DNA banding patterns. BioTechniques 14:214-217.

Evanno, G., Regnaut, S., and Goudet, J. 2005. Detecting the number of clusters of individuals using the software STRUCTURE: A simulation study. Mol. Ecol. 14:2611-2620.

Excoffier, L., Laval, G., and Schneider, S. 2005. Arlequin ver. 3.0: An integrated software package for population genetics data analysis. Evol. Bioinf. Online 1:47-50.

Excoffier, L., Smouse, P., and Quattro, J. 1992. Analysis of molecular variance inferred from metric distances among DNA haplotypes: Application to mitochondrial DNA restriction data. Genetics 131:479-491.

Falush, D., Stephens, M., and Pritchard, J. K. 2007. Inference of population structure using multilocus genotype data: Dominant markers and null alleles. Mol. Ecol. 7:574-578.

Forgan, A. H., Knogge, W., and Anderson, P. A. 2007. Asexual genetic exchange in the barley pathogen Rhynchosporium secalis. Phytopathology 97:650-654.

Gladieux, P., Zhang, X. G., Afoufa-Bastien, D., Sanhueza, R. M. V., Sbaghi, M., and Le Cam, B. 2008. On the origin and spread of the scab disease of apple: Out of Central Asia. PLoS One 3:e1455.

Gladieux, P., Zhang, X.-G., Róldan-Ruiz, I., Caffier, V., Leroy, T., Devaux, M., van Glabeke, S., Coart, E., and Le Cam, B. 2010. Evolution of the population structure of Venturia inaequalis, the apple scab fungus, associated with the domestication of its host. Mol. Ecol. 19:658-674.

Goff, W. D., McVay, J. R., and Gazaway, W. S. 1996:Page 222 in: Pecan Production in the Southeast. Ala. Coop. Ext. Syst. Circ. ANR-459. University of Alabama, Auburn.
Gottwald, T. R. 1985. Influence of temperature, leaf wetness period, leaf age, and spore concentration on infection of pecan leaves by conidia of Cladosporium caryigenum. Phytopathology 75:190-194.

Gottwald, T. R., and Bertrand, P. F. 1982. Patterns of diurnal and seasonal airborne spore concentrations of Fusicladium effusum and its impact on a pecan scab epidemic. Phytopathology 72:330-335.

Gottwald, T. R., and Bertrand, P. F. 1983. Effect of time of inoculation with Cladosporium caryigenum on pecan scab development and nut quality. Phytopathology 73:714-718.

Grauke, L. J., Mendoza-Herrera, M., Miller, A., and Wood, B. W. 2011. Geographic patterns of genetic variation in native pecans. Tree Genet. Genomes 7:917-932.

Grauke, L. J., Wood, B. W., and Harris, M. L. 2016. Crop vulnerability: Carya. HortScience 51:653-663.

Groenewald, M., Barnes, I., Bradshaw, R. E., Brown, A. V., Dale, A., Groenewald, J. Z., Lewis, K. J., Wingfield, B. D., Wingfield, M. J., and Crous, P. W. 2007. Characterization and distribution of mating type genes in the Dothistroma needle blight pathogens. Phytopathology 97:825-834.

Grünwald, N. J., Goodwin, S. B., Milgroom, M. G., and Fry, W. E. 2003. Analysis of genotypic diversity data for populations of microorganisms. Phytopathology 93:738-746.

Guérin, F., Gladieux, P., and Le Cam, B. 2007. Origin and colonization history of newly virulent strains of the phytopathogenic fungus Venturia inaequalis. Fungal Genet. Biol. 44:284-292.

Hirst, P., Richardson, T. E., Carson, S. D., and Bradshaw, R. E. 1999. Dothistroma pini genetic diversity is low in New Zealand. N. Z. J. For. Sci. 29:459-472.

Kamvar, Z. N., Tabima, J. F., and Grünwald, N. J. 2014. Poppr: An R package for genetic analysis of populations with clonal, partially clonal, and/or sexual reproduction. PeerJ 2:e281.

Kobayashi, T. 1984. Notes on fungi parasitic to woody plants in Paraguay. Trans. Mycol. Soc. Japan 25:255-273.

Latham, A. J. 1982. Effect of some weather factors and Fusicladium effusum conidium dispersal on pecan scab occurrence. Phytopathology 72:1339-1345.

Linde, C. C., Liles, J. A., and Thrall, P. H. 2010. Expansion of genetic diversity in randomly mating founder populations of Alternaria brassicicola infecting Cakile maritima in Australia. Appl. Environ. Microbiol. 76:1946-1954.

Linde, C. C., Zala, M., Ceccarelli, S., and McDonald, B. A. 2003. Further evidence for sexual reproduction in Rhynchosporium secalis based on distribution and frequency of mating-type alleles. Fungal Genet. Biol. 40:115-125.

Linde, C. C., Zala, M., and McDonald, B. A. 2009. Molecular evidence for recent founder populations and human-mediated migration in the barley scald pathogen Rhynchosporium secalis. Mol. Phylogenet. Evol. 51:454-464.

Linde, C. C., Zhan, J., and McDonald, B. A. 2002. Population structure of Mycosphaerella graminicola: From lesions to continents. Phytopathology 92:946-955.

Ludwig, J. A., and Reynolds, J. F. 1988. Statistical Ecology: A Primer in Methods and Computing. John Wiley \& Sons.

Luikart, G., and Cornuet, J. M. 1998. Empirical evaluation of a test for identifying recently bottlenecked populations from allele frequency data. Conserv. Biol. 12:228-237.

Manly, B. F. J. 1994. Multivariate Statistical Methods: A, 2nd ed. Chapman \& Hall, New York.

Mantz, G., Rollán, C., Ronco, L., and Maiale, S. 2009. First report of pink mold on Pecan nuts in Argentina. J. Plant Pathol. 91:238.

McDonald, B. A. 2015. How can research on pathogen population biology suggest disease management strategies? The example of barley scald (Rhynchosporium commune). Plant Pathol. 64:1005-1013.

McDonald, B. A., and Linde, C. 2002. Pathogen population genetics, evolutionary potential, and durable resistance. Annu. Rev. Phytopathol. 40:349-379.

McDonald, B. A., and Mundt, C. C. 2016. How knowledge of pathogen population biology informs management of Septoria tritici blotch. Phytopathology 106:948-955

McDonald, B. A., Pettway, R. E., Chen, R. S., Boeger, J. M., and Martinez, J. P. 1995. The population genetics of Septoria tritici (teleomorph Mycosphaerella graminicola). Can. J. Bot. 73:292-301.

McDonald, B. A., Zhan, J., and Burdon, J. J. 1999. Genetic structure of Rhynchosporium secalis in Australia. Phytopathology 89:639-645.

McDonald, M. C., McDonald, B. A., and Solomon, P. S. 2015. Recent advances in the Zymoseptoria tritici-wheat interaction: Insights from pathogenomics. Front. Plant Sci. 6.

Mendes, M. A. S., da Silva, V. L., Dianese, J. C., Ferreira, M. A. S. V., dos Santos, C. E. N., Neto, E. G., Urben, A. F., and Castro, C. 1998. Fungos em Plantas no Brasil. Embrapa-SPI/Embrapa-Cenargen, Brasilia, DF.

NASS. 2015. Pecan production statistics for 2015. Online publication. United States Department of Agriculture National Agricultural Statistics Service. https://quickstats.nass.usda.gov/results/29594F91-5ED0-3A4E-8F5E4C26CC0071D8 
Nei, M. 1973. Analysis of gene diversity in subdivided populations. Proc. Natl. Acad. Sci. USA 70:3321-3323.

Nei, M. 1978. Estimation of average heterozygosity and genetic distance from a small number of individuals. Genetics 89:583-590.

Nei, M. 1987. Molecular Evolutionary Genetics. Columbia University Press, New York.

Nei, M., Maruyama, T., and Chakraborty, R. 1975. The bottleneck effect and genetic variability in populations. Evol. 29:1-10.

Novelo, N. D., Gomelsky, B., and Pomper, K. W. 2010. Inheritance and reliability of random amplified polymorphic DNA-markers in two consecutive generations of common carp (Cyprinus carpio L.). Aquacult. Res. 41:220-226.

Peakall, R., and Smouse, P. E. 2012. GenAlEx 6.5: Genetic analysis in Excel. Population genetic software for teaching and research-An update. Bioinformatics 28:2537-2539.

Pennycook, S. R., Young, J. M., Fletcher, M. J., and Fry, P. A. 1989. Plant Diseases Recorded in New Zealand, Vol. 1-3. Plant Diseases Division, DSIR, Auckland, New Zealand.

Petit, R. J., and Hampe, A. 2006. Some evolutionary consequences of being a Tree. Annu. Rev. Ecol. Evol. Syst. 37:187-214.

Pielou, E. C. 1975. Ecological Diversity. Wiley, New York.

Piry, S., Luikart, G., and Cornuet, J. M. 1999. Bottleneck: A computer program for detecting recent reductions in the effective population size using allele frequency data. J. Hered. 90:502-503.

Pontecorvo, G. 1956. The parasexual cycle in fungi. Annu. Rev. Microbiol. 10: 393-400.

Pritchard, J. K., Stephens, M., and Donnelly, P. 2000. Inference of population structure using multilocus genotype data. Genetics 155:945-959.

Quaedvlieg, W., Kema, G. H. J., Groenewald, J. Z., Verkley, G. J. M., Seifbarghi, S., Razavi, M., Mirzadi Gohari, A., Mehrabi, R., and Crous, P. W. 2011. Zymoseptoria gen. nov.: A new genus to accommodate Septoria-like species occurring on graminicolous hosts. Persoonia Mol. Phylogenet. Evol. Fungi 26:57-69.

Rossman, A. Y., Allen, W. C., and Castlebury, L. A. 2016. New combinations of plant associated fungi resulting from the change to one name for fungi. IMA Fungus 7:1-7.

Salamati, S., Zhan, J., Burdon, J. J., and McDonald, B. A. 2000. The genetic structure of field populations of Rhynchosporium secalis from three continents suggests moderate gene flow and regular recombination. Phytopathology 90:901-908.

Schubert, K., Ritschel, A., and Braun, U. 2003. A monograph of Fusicladium s. lat. (Hyphomycetes). Schlechtendalia 9:1-132.

Schuelke, M. 2000. An economic method for the fluorescent labelling of PCR fragments. Nat. Biotechnol. 18:233-234.

Seyran, M., Nischwitz, C., Lewis, K. J., Gitaitis, R. D., Brenneman, T. B., and Stevenson, K. L. 2010. Phylogeny of the pecan scab fungus Fusicladium effusum G. Winter based on the cytochrome b gene sequence. Mycol. Prog. 9:305-308.

Shannon, C. E. 2001. A mathematical theory of communication. ACM SIGMOBILE Mob. Comput. Commun. Rev. 5:3-55.

Simpson, E. 1949. Measurement of diversity. Nature 163:688.

Smith, J. M., Smith, N. H., O’Rourke, M., and Spratt, B. G. 1993. How clonal are bacteria? Proc. Nat. Acad. Sci. 90:4384-4388.
Spencer, C. C., Neigel, J. E., and Leberg, P. L. 2000. Experimental evaluation of the usefulness of microsatellite DNA for detecting demographic bottlenecks. Mol. Ecol. 9:1517-1528.

Stevenson, K. L. 1999. Fungicide resistance management in pecans. Southeast. Pecan Grow. Assoc. 92:58-64.

Stevenson, K. L., and Bertrand, P. F. 2001. Within-season dynamics of yield loss due to pecan scab fruit infections. (Abstr.) Phytopathology 91:S85.

Stevenson, K. L., Brenneman, T. B., and Brock, J. 2014. Results of the 2014 pecan scab fungicide sensitivity monitoring program. Georgia Pecan Grower's Magazine 26:16-23.

Stoddart, J. A., and Taylor, J. F. 1988. Genotypic diversity: Estimation and prediction in samples. Genetics 118:705-711.

Stukenbrock, E. H., Bataillon, T., Dutheil, J. Y., Hansen, T. T., Li, R., Zala, M., McDonald, B. A., Wang, J., and Schierup, M. H. 2011. The making of a new pathogen: Insights from comparative population genomics of the domesticated wheat pathogen Mycosphaerella graminicola and its wild sister species. Genome Res. 21:2157-2166.

Stukenbrock, E. H., and McDonald, B. A. 2008. The origins of plant pathogens in agro-ecosystems. Annu. Rev. Phytopathol. 46:75-100.

Taylor, J., Jacobson, D., and Fisher, M. 1999. The evolution of asexual fungi: Reproduction, speciation and classification. Annu. Rev. Phytopathol. 37:197-246.

Tenzer, I., degli Ivanissevich, S., Morgante, M., and Gessler, C. 1999. Identification of microsatellite markers and their application to population genetics of Venturia inaequalis. Phytopathology 89:748-753.

Tenzer, I., and Gessler, C. 1999. Genetic diversity of Venturia inaequalis across Europe. Eur. J. Plant Pathol. 105:545-552.

Teviotdale, B. L., Michailides, T. J., and Pscheidt, J. W., eds. 2002. Page 89 in: Compendium of Nut Crop Diseases in Temperate Zones. American Phytopathological Society Press, St. Paul, MN.

Wells, M. L. 2014. Pecan planting trends in Georgia. HortTechnology 24: 475-479.

Winter, G. 1885. New North America fungi. J. Mycol. 1:101-102.

Worley, R. E. 2002. Compendium of Pecan Production and Research. Edwards Brothers Inc., Ann Arbor, MI.

Wright, S. 1969. Evolution and the Genetics of Populations: The Theory of Gene Frequencies. The University of Chicago Press, Chicago.

Xu, X., Harvey, N., Roberts, A., and Barbara, D. 2013. Population variation of apple scab (Venturia inaequalis) within mixed orchards in the UK. Eur. J. Plant Pathol. 135:97-104.

Zaffarano, P. L., McDonald, B. A., and Linde, C. C. 2011. Two new species of Rhynchosporium. Mycologia 103:195-202.

Zaffarano, P. L., McDonald, B. A., Zala, M., and Linde, C. C. 2006. Global hierarchical gene diversity analysis suggests the Fertile Crescent is not the center of origin of the barley scald pathogen Rhynchosporium secalis. Phytopathology 96:941-950.

Zhan, J., Pettway, R. E., and McDonald, B. A. 2003. The global genetic structure of the wheat pathogen Mycosphaerella graminicola is characterized by high nuclear diversity, low mitochondrial diversity, regular recombination, and gene flow. Fungal Genet. Biol. 38:286-297. 